VERTAISARVIOITU

KOLLEGIALT GRANSKAD

PEER-REVIEWED

www.tsv.fi/tunnus

\title{
SUOMEN KIELEN KÄYTTÄMISEN JA OPPIMISEN MAHDOLLISUUDET AMMATILLISEN OPPILAITOKSEN RAKENNUSALAN VUOROVAIKUTUSTILANTEISSA
}

\author{
Niina Lilja, Tampereen yliopisto \\ Terhi Tapaninen, Tampereen yliopisto ja Tampereen \\ aikuiskoulutuskeskus
}

\begin{abstract}
Viime vuosina työelämään osallistumisen merkitystä kotoutumisessa on korostettu yhä enemmän. Erityisesti aikuiset maahanmuuttajat halutaan integroida työelämään mahdollisimman nopeasti paitsi taloudellisista syistä myös siksi, että maahanmuuttajien mukanaan tuoma tietotaito saataisiin käyttöön. Yhtenä tehokkaana tapana integroida maahanmuuttajia työmarkkinoille on pidetty kielenopetuksen yhdistämistä ammatilliseen opetukseen. Aikuisten kotoutumiskoulutukseen onkin kehitetty uudet toteutusmallit, joissa painotetaan ammatillista kielitaitoa ja koulutuksen työelämärelevanssia. Uudet toteutusmallit tuovat kotoutumiskoulutukseen haasteita, koska tutkittua tietoa siitä, millaista kielitaitoa eri ammateissa ja työtehtävissä tarvitaan, on olemassa vasta vähän. Erityisesti suorittavan työn työtehtävien kielikäytänteiden tutkimus on vähäistä niin meillä Suomessa kuin kansainvälisestikin.

Tarkastelemme tässä artikkelissa rakennusalan työtehtävien kielikäytänteitä ammatillisen kotoutumiskoulutuksen työtilanteissa. Aineisto on kerätty video- ja ääninauhoittamalla rakennusalan työtilanteita yhden viikon ajan. Analyysimenetelmänä on multimodaalinen keskustelunanalyysi. Analyysi osoittaa, että rakennusalan vuorovaikutustilanteissa kielen käyttö on hyvin kiinteässä yhteydessä tilanteen materiaaliseen ja fyysiseen ympäristöön. Tilanteissa korostuu ohjaileva toiminta: tarvitaan taitoa ohjeistaa työtovereita ja pyytää heiltä työkaluja tai apua, ja tässä myös ammattialan erikoissanaston osaaminen on tärkeää.
\end{abstract}

Avainsanat: keskustelunanalyysi, kielen oppiminen, oppiminen, suomi toisena kielenä, suorittava työ, työelämän kieli, vuorovaikutus

Kirjoittajien yhteystiedot:

Niina Lilja

niina.lilja@tuni.fi

Terhi Tapaninen

terhi.tapaninen@takk.fi

\section{JOHDANTO}

"Työelämään osallistuminen antaa maahanmuuttajalle kielitaidon ja verkostot", todetaan eduskunnan tarkastusvaliokunnan julkaisussa kotouttamistoimenpiteiden vaikuttavuudesta (Eduskunta, 2018, s. 8). Paikallisen kielen 
oppimista on pidetty kotoutumisen kannalta ensiarvoisena. Viime vuosina työelämään osallistumisen merkitystä kotoutumisessa on kuitenkin korostettu yhä enemmän. Erityisesti aikuiset maahanmuuttajat halutaan integroida työelämään mahdollisimman nopeasti paitsi taloudellisista syistä myös siksi, että maahanmuuttajien mukanaan tuoma tietotaito saataisiin käyttöön (ks. Hallituksen kotouttamista koskeva toimintasuunnitelma, 2016; Valtion kotouttamisohjelma vuosille 2016-2019). OECD-maista kerättyjen tietojen perusteella tehokas tapa integroida maahanmuuttajia työmarkkinoille on kielenopetuksen yhdistäminen ammatilliseen opetukseen (OECD, 2017, s. 37, 41).

Tutkittua tietoa siitä, miten työelämään osallistuminen "antaa" kielitaidon ja millaista kielitaitoa eri ammateissa ja työtehtävissä todellisuudessa tarvitaan tai vaaditaan, on kuitenkin olemassa vasta vähän (ks. Kieliparlamentti, 2011; Pyykkö, 2017, s. 102, 114). Erityisesti suorittavan ${ }^{1}$ työn työtehtävien kielikäytänteiden tutkimus on vähäistä niin meillä Suomessa kuin kansainvälisestikin (ks. Lønsmann \& Kraft, 2017). Ne muutamat tutkimukset, joita suorittavan työn kielikäytänteistä on tehty, ovat kuitenkin nostaneet esiin olennaisia havaintoja siitä, miten kieli on tai ei ole merkityksellinen työn tekemisen näkökulmasta. Joillakin aloilla, kuten vaikkapa tehdas- ja siivoustyössä, kielen käytön mahdollisuudet voivat työn luonteen vuoksi olla vähäiset (ks. esim. Piller \& Lising, 2014; Strömmer, 2017). Toisilla aloilla, kuten esimerkiksi rakennusalalla, taas kieltä tarvitaan hyvin monipuolisesti työtehtävien hoitamisessa, ja useimmissa töissä pai-

1 Puhumme tässä suorittavasta työstä viitatessamme työhön, joka on luonteeltaan fyysistä ja manuaalista, kuten tehdastyö, rakennustyö tai monet maatalouteen liittyvät työt. Englanninkielisessä kirjallisuudessa käytetään samassa yhteydessä usein termiä blue-collar. (Ks. esim. Lønsmann \& Kraft, 2017.) kallisen kielen osaaminen on ensiarvoisen tärkeää työyhteisöön sosiaalistumisen kannalta (ks. esim. Holmes \& Woodhams, 2013).

Suomessa rakennusala on yksi tärkeä maahanmuuttajataustaisten aikuisten työllistäjä (ks. Sutela, 2015), ja esimerkiksi vuoden 2015 syksyllä tulleiden turvapaikanhakijoiden parissa tehdyn kyselyn perusteella rakennusalan aikaisempaa työkokemusta oli 27 prosentilla kyselyyn osallistuneista aikuisista maahanmuuttajista (Sandberg \& Strodell, 2016, s. 24). Rakennusalaa voi aikaisemman tutkimuksen perusteella pitää sellaisena suorittavan työn alana, jossa vuorovaikutus- ja kielitaito on työssä keskeisellä sijalla: työtehtävien tekemiseen liittyy paljon neuvottelua ja toiminnan koordinointia ja myös työyhteisöön sosiaalistumisen näkökulmasta kieli on tärkeä (Holmes \& Woodhams, 2013; Svennevig, 2017).

Tarkastelemme tässä artikkelissa rakennusalan työtehtävien kielikäytänteitä ammatillisen kotoutumiskoulutuksen työtilanteissa. Kysymme, millaiset kielenkäytön tavat ovat rakennusalalla tyypillisiä ja toistuvia ja miten kielen oppiminen työtehtävien lomassa mahdollisesti tapahtuu. Tutkimuksemme lähti liikkeelle käytännön tarpeesta: teimme kotoutumiskoulutuksen suomen kielen opettajan kanssa yhteistyötä ja pohdimme, miten opiskelijoiden suomen kielen käyttöä ja oppimista kieliluokkien ulkopuolella olisi mahdollista tukea (ks. Arjen vuorovaikutusta muotoilemassa, 2018). Opettajan opetettavana oli uusien kotoutumiskoulutuksen toteuttamismallien mukaan organisoitu ryhmä, joka osallistui joka toinen viikko kielikoulutukseen ja joka toinen viikko rakennusalan työtehtäväpainotteisiin opintoihin. Teimme opiskelijoiden kanssa tehtäviä, joiden tavoitteena oli ohjata heitä tunnistamaan rakennusalalle tyypillisiä kielenkäyttötilanteita ja tukea heidän kielenkäyttöään ja oppimistaan työtehtävien lomassa. Työelämän kielen opet- 
taminen on kuitenkin haastavaa tilanteessa, jossa tutkittua tietoa suorittavan työn kielija vuorovaikutuskäytänteistä on vasta vähän. Myös ammattiopettajat ovat haasteen edessä, kun heidän opetettavanaan on koko ajan suurempi joukko opiskelijoita, joille suomi on toinen kieli ja joiden kielitaidon kehittymistä täytyisi tukea sen lisäksi, että heidän ammatillista osaamistaan kartoitetaan ja heille opetetaan ammateissa tarvittavia taitoja. Jotta sekä kielten että ammattiopettajien olisi mahdollista tukea kielen oppimista työtehtävien aikana, tarvitaan tutkimukseen perustuvaa tietoa siitä, millaisia kielenkäyttötilanteita työtehtäviin liittyy ja millaista kieltä niissä toimimiseen tarvitaan. Tästä lähtökohdasta lähdimme nauhoittamaan rakennusalan työtilanteita tavoitteenamme saada selville, millaista kieltä niissä käytetään ja tarvitaan. Tutkimuksemme tavoitteena on siis luoda tätä tietoa ja tuoda lisää ymmärrystä kielenkäytöstä ja oppimisesta suorittavaan työhön liittyvissä vuorovaikutustilanteissa.

Tutkimuksemme analyyttisena lähtökohtana on multimodaalinen keskustelunanalyysi (ks. Mondada, 2014, 2016). Keskustelunanalyyttisen tutkimuksen tavoitteena on tehdä näkyviksi niitä vuorovaikutuksen keinoja, joiden avulla ihmiset rakentavat yhteistä ymmärrystä erilaisissa vuorovaikutusympäristöissä. Yleensä analyysi keskittyy johonkin tiettyyn vuorovaikutusilmiöön, kuten vaikka tietyllä tavalla rakennettuihin ohjaileviin vuoroihin (ks. Sorjonen, Raevaara \& CouperKuhlen, 2017). Tässä artikkelissamme sovellamme keskustelunanalyyttisia lähtökohtia, koska tavoitteenamme ei ole minkään yksittäisen vuorovaikutusilmiön analyysi sinänsä vaan laajemmin sen selvittäminen, millaiset kielikäytänteet ovat rakennusalan vuorovaikutustilanteissa toistuvia. Aineistomme tilanteissa monenlainen ohjaileva puhetoiminta nousee keskiöön: opettajat antavat ohjeita ja osallistujat ohjaavat toistensa toimintaa eri- laisin direktiivein ja pyynnöin. Siksi analyysissamme nousee esiin näkökulmia erityisesti siihen, miten nämä ohjailevat puhetoiminnot toteutuvat rakennusalalle tyypillisissä vuorovaikutusympäristöissä.

Koska tutkimuksemme aineisto on peräisin aikuisten kotoutumiskoulutuksesta ja koska tavoitteenamme on tuottaa tietoa, josta olisi apua koulutuksen kehittämisessä, lähdemme tekstissämme liikkeelle taustoittamalla kotoutumiseen liittyvää kehitystä ja erityisesti kotoutumiskoulutuksen sisällöissä viime vuosina tapahtunutta kehitystä. Sen jälkeen käymme läpi analyysimme kannalta olennaista aikaisempaa tutkimusta suorittavan työn kielikäytänteistä. Luvussa neljä esittelemme aineistomme ja analyysimenetelmän. Viidennessä luvussa esitämme keskeisiä analyysissa tekemiämme havaintoja ja havainnollistamme niitä aineistonäyttein. Lopuksi pohdimme, mitä havaintomme tarkoittavat suhteessa kotoutumiskoulutuksen nykytilanteeseen, ja perustelemme, millaista jatkotutkimusta tästä aihepiiristä tarvitaan.

\section{KOTOUTUMISKOULUTUS MUUTOKSESSA}

Maahanmuutto Pohjoismaihin on kasvanut nopeasti; Suomeen etenkin 1990-luvun alusta alkaen. Muualla syntyneiden osuus Suomen koko väestöstä on tilastojen mukaan kasvanut 148 prosenttia vuodesta 2000 vuoteen 2015 (Pyrhönen, Leinonen \& Martikainen, 2017 , s. 14). Toistaiseksi maahanmuuton huippuvuosi on ollut vuonna 2015, jolloin turvapaikanhakijoiden määrä kasvoi yhtäkkisesti koko Euroopassa ja Suomeen saapui kaiken kaikkiaan 32476 turvapaikanhakijaa (Hallituksen kotouttamista koskeva toimintasuunnitelma, 2016). Maahanmuuttajien asettumista Suomeen pyritään edistämään kotouttamistoimenpiteillä, joihin kuuluvat esimerkiksi kotoutumiskoulutus ja muut 
työllistymistä tukevat toimenpiteet. Vuonna 2012 julkaistuissa Aikuisten maahanmuuttajien kotoutumiskoulutuksen opetussuunnitelman perusteissa kotoutumiskoulutus on määritelty suomen tai ruotsin kielen opetukseksi sekä muuksi opetukseksi, joka edistää maahanmuuttajan yhteiskunnallisia, kulttuurisia ja elämänhallintaan liittyviä valmiuksia sekä pääsyä työelämään ja jatkokoulutukseen. Kotoutumiskoulutuksen kielellisenä tavoitteena on toimiva peruskielitaito (Eurooppalaisen viitekehyksen mukainen taitotaso B1.1.) (OPH, 2012).

Yhtenä onnistuneen kotoutumisen tärkeimmistä mittareista pidetään maahanmuuttajien työllistymistä ja jatko-opintoihin sijoittumista. Muihin OECD-maihin verrattuna Pohjoismaissa on erityisen suuret erot maahanmuuttajataustaisten ja kantaväestön välisissä työllisyysluvuissa. Varsinkin pakolaistaustaisten maahanmuuttajien työllistyminen on Pohjoismaissa vaikeaa (Karlsdóttir, Sigurjónsdóttir, Hildestrand \& Cuadrado, 2017, s. 10). Tilastojen mukaan esimerkiksi Ruotsissa ja Tanskassa vain noin 20 prosenttia pakolaistaustaisista maahanmuuttajista työskentelee kahden vuoden maassaolon jälkeen. Työskentelevien osuus lisääntyy maassaolovuosien myötä ja keskimäärin maahanmuuttajan työllistyminen kestää viidestä kymmeneen vuotta. Silti vielä $10-15$ vuoden maassaolon jälkeen pakolaistaustaisten maahanmuuttajien työllisyystilanne on merkittävästi huonompi kuin maiden syntyperäisten kansalaisten (Joyce, 2018). Suomessa tilastot kertovat samaa. Kaikkien maahanmuuttajien keskuudessa työllisyysaste on parempi pidempään maassa asuneilla: Ulkomaista syntyperää olevien työ ja hyvinvointi 2014 -tutkimuksen mukaan alle viisi vuotta Suomessa asuneilla työllisyysaste oli vain 56 prosenttia, kun yli 10 vuotta asuneilla se oli 69 prosenttia, mikä läheni tilaston julkaisemisvuoden 2014 kantaväestön työllisyysastetta (Nieminen, Sutela
\& Hannula, 2014, s. 75-76). On kuitenkin myös havaittu, että erityisesti Virosta kotoisin olevien maahanmuuttajien hyvä työllistyminen hämärtää sen seikan erottumista tilastoissa, että erityisesti Euroopan unionin ulkopuolella muuttavien henkilöiden työllistyminen on ollut Suomessa heikkoa - jopa heikointa OECD-maissa (ks. OECD, 2018).

Maahanmuuttajien pääsyä työelämään on Pohjoismaissa pyritty viime vuosina vauhdittamaan erilaisin hankkein. Esimerkiksi Tanskassa on käynnistetty IGU-koulutus, jossa uudet pakolaistaustaiset maahanmuuttajat työskentelevät tanskalaisissa yrityksissä ja heille tarjotaan työskentelyyn yhdistettynä alkeistason kielenopetusta. Norjassa nopeutetun työelämään pääsyn mahdollistamiseksi on aloitettu esimerkiksi Hurtigsporet-ohjelma (Pikaraide) motivoituneille pakolaistaustaisille aikuisille, ja hoitoalan työpaikoissa on käynnistetty työssäoppimisjaksoja, joissa keskitytään maahanmuuttajien ammatillisten taitojen, työelämätaitojen ja norjan kielen parantamiseen. Ruotsissa on käynnistetty vuoden 2016 jälkeen 14 Snabbspår-hanketta (Pikaraide) työvoimapula-aloille (Karlsdóttir ym., 2017, s. 20-22). Suomessa tällaisia nopeaan työllistymiseen tähtääviä hankkeita ovat esimerkiksi KIITO-hanke (ks. KIITO), jossa opiskelijalle etsitään osaamiskartoituksen perusteella sopiva työpaikka ja kielenopetus viedään työpaikalle, sekä vaikuttavuusinvestoimiseen perustuva SIB-hanke (ks. Social Impact Bond), jonka rahoittavat sijoittajat. Sijoittajat saavat valtiolta oman panoksensa takaisin, jos hanke onnistuu työllistymistavoitteissaan, mutta jos hanke ei onnistu työllistämistavoitteissaan, kulut jäävät sijoittajien maksettavaksi. Kaikkien näiden hankkeiden kantavana ajatuksena on jouduttaa aikuisten maahanmuuttajien kotoutumista helpottamalla työelämään pääsyä ja osaamisen tunnistamista ja tunnustamista.

Maahanmuuttajien kantaväestöä heikom- 
pi työllisyystilanne on kasvattanut paineita kotoutumiskoulutuksen uudistamiseen ja työelämälähtöisyyden lisäämiseen. Hallituksen ministeriöiden välisessä yhteistyössä valmistui vuonna 2016 uusi kotouttamista koskeva toimintasuunnitelma. Suunnitelmassa linjataan koulutuksen ja työelämään siirtymisen nopeuttamiseksi muun muassa seuraavia toimenpiteitä: kotoutumiskoulutuksen ja sitä seuraavien koulutusten rajaaitoja madalletaan, osaamisen tunnistamista ja tutkintojen tunnustamista tehostetaan, kotoutumiskoulutuksen toteutusta uudistetaan ja suunnataan ammatillisesti painottunutta kotoutumiskoulutusta etenkin työvoimapula-aloille (Hallituksen kotouttamista koskeva toimintasuunnitelma, 2016).

Hallituksen toimintasuunnitelman mukaisesti kotoutumiskoulutukseen otettiin käyttöön uudet työelämälähtöisemmät ja ammatillisesti suuntautuneet mallit vuonna 2016. Uusissa toteutusmalleissa työelämään ja jatko-opintoihin johtavaa polkua pyritään nopeuttamaan nivomalla kielenopiskelua esimerkiksi ammatillisiin opintoihin, vapaaehtoistyöhön sekä verkko- ja etäopiskeluun (ks. Päivitetyt kotoutumiskoulutuksen toteutusmallit 2017). Tätä uudenmuotoista kotoutumiskoulutusta on toteutettu vasta suhteellisen lyhyen aikaa. Pääkaupunkiseudulla ja Turussa kokeiltujen käytänteiden toimivuudesta on kuitenkin tehty jo selvitystyö, jonka mukaan erityisesti opettajat pitivät muutosta tervetulleena ja oikeansuuntaisena, vaikka muutos onkin vaatinut heiltä paljon uuden opettelemista (ks. Uudenmaan ELY, 2018; ks. myös OECD, 2018). Tämän tutkimuksemme aineisto on myös peräisin uusien kotoutumiskoulutuksen mallien mukaisesti järjestetyiltä koulutusjaksoilta.

\section{KIELIKÄYTÄNTEET JA KIELEN OPPIMISEN MAHDOLLISUUDET SUORITTAVASSA TYÖSSÄ}

Työelämän kieltä, kieli- ja vuorovaikutuskäytänteitä ja kielitaitotarpeita on viime vuosina tutkittu yhä aktiivisemmin niin Suomessa kuin kansainvälisesti. Tutkimus on kuitenkin suurelta osalta kohdistunut asiantuntijaaloihin, joissa työ tapahtuu paljon vuorovaikutuksen, kielen ja tekstien parissa (ks. esim. Johansson, Nuolijärvi \& Pyykkö, 2011; Kalliokoski, 2017; Vaattovaara, 2017). Suorittavan tai fyysisen työn kielikäytänteitä on tutkittu vähemmän. Olemassa oleva tutkimus näyttää kuitenkin selvästi sen, että vaikka suorittavan työn tehtäviä yhdistää usein fyysisyys ja manuaalisuus, vuorovaikutuksen ja kielen käytön näkökulmasta työtehtävät eroavat toisistaan selvästi (ks. esim. Lønsmann \& Kraft, 2017).

Joissakin tutkimuksissa nousee esiin ajatus siitä, että suorittavan työn työtehtäviin liittyy rajallisesti kielenkäyttötilanteita. Näin on havaittu olevan esimerkiksi tehdas- ja siivoustyössä (Goldstein, 1996; Piller \& Lising, 2014). Piller ja Lising (2014) tutkivat teurastamotyössä Australiassa työskentelevien englanti toisena kielenä -puhujien kielikäytänteitä. Heidän havaintojensa mukaan teurastamotyö oli niin kiivastahtista ja fyysisesti vaativaa, että aikaa vuorovaikutukseen, kielenkäyttöön tai oppimiseen ei työn lomassa ollut. Goldstein (1996) puolestaan seurasi etnografisessa tutkimuksessaan portugalilaisia tehtaan linjastolla työskenteleviä naisia Kanadassa ja havaitsi, että paikallisen kielen eli englannin osaaminen ei näille työntekijöille ollut olennaista työn suorittamisen näkökulmasta, koska he pärjäsivät työssä myös äidinkielellään. Se, että kieltä ei juuri tarvittu työssä, vähensi osaltaan työntekijöiden motivaatiota kielen opiskeluun, vaikka työnantaja tarjosi heille kielikoulutusta lounastaukojen 
aikana. Strömmer (2017) analysoi väitöskirjassaan suomen kielen käyttämisen ja oppimisen mahdollisuuksia siivoustyössä. Hän osoittaa, että kielen oppimisen mahdollisuudet siivoustyössä ovat rajalliset työn rutiininomaisuuden sekä itsenäisen luonteen vuoksi. Siivoustyö on usein kilpailutettua, mistä syytä työntekijän on kuljettava siivouskohteesta toiseen ja mahdolliset kollegat vaihtuvat usein. Näin ollen pysyviä vuorovaikutussuhteita kollegoihin tai siivouskohteissa työskenteleviin henkilöihin ei ehdi syntyä, mikä vähentää mahdollisuutta puhua suomeksi ja harjoitella kieltä. Strömmer toteaakin, että työntekijän sosiaalisella ympäristöllä on suuri vaikutus kielen oppimisen mahdollisuuksiin.

Toisissa tutkimuksissa kielen merkitys myös suorittavassa työssä kuitenkin korostuu. Esimerkiksi juuri rakennusalan työtehtävissä kielellä näyttäisi olevan tärkeä rooli. Holmes ja Woodhams (2013) ovat tutkineet rakennustyön kielikäytänteitä Uudessa-Seelannissa ja analysoineet erityisesti, miten työntekijät osoittavat ja neuvottelevat omaa asemaansa ammattiyhteisön jäsenenä kielen keinoin. Heidän analyysinsa havainnollistaa, miten erityyppiset direktiivit ja niihin reagoiminen ovat olennainen osa ammatissa tarvittavaa kielitaitoa. He kuitenkin korostavat tutkimuksessaan myös havaintoa siitä, että työhön liittyy paljon suhteita ylläpitävää rupattelua, ja siirtymät sosiaalisia suhteita ylläpitävän juttelun ja työtehtäviä eteenpäin vievän keskustelun välillä ovat nopeita. Heidän analyysinsa mukaan siis työyhteisössä toimiminen edellyttää monipuolista kielitaitoa rakennusalan ammattilaisilta. Kraft (2017) on tehnyt väitöskirjan kielikäytänteistä norjalaisilla rakennusalan työpaikoilla, joilla työskentelee paljon väliaikaisia vierastyöläisiä. Hänen analyysinsa osoittaa, että kielen osaamiseen kytkeytyy esimerkiksi työtehtävähierarkiassa eteneminen: norjan kielen taito on edellytys esimiesasemaan nousemisessa. Kielen oppi- minen nähtiin Kraftin havaintojen mukaan näillä työpaikoilla kuitenkin enemmän yksilön omalla vastuulla olevaksi asiaksi, eikä yritys esimerkiksi järjestänyt kielikoulutusta, vaikka yhteisen ymmärryksen saavuttaminen onkin työn onnistumisen edellytys. Kraftin analyysi nostaa esiin sen problematiikan, joka liittyy työmarkkinoiden globaalistumiseen ja siihen kytkeytyviin kysymyksiin talouden vaikutuksesta työn organisointiin ja eritaustaisten henkilöiden asemaan ja mahdollisuuksiin työmarkkinoilla. Kielitaito toisaalta mahdollistaa työssä etenemisen, mutta toisaalta kielitaitoa tai erityisesti jonkun tietyn kielen taidon puuttumista käytetään usein myös sulkemaan ihmisiä pois työelämästä joskus vailla varsinaista perustetta (ks. Kraft, 2017). Tässä mainituista tutkimuksista muutkin nostavat esiin ongelmallisuuden, joka liittyy tilanteisiin, joissa työn ohessa ei ole mahdollisuutta oppia kieltä. Jos maahanmuuttaja kotoutumisen alkuvaiheessa ohjataan "sisääntuloammattiin", jossa ei ole mahdollista oppia kieltä, sisääntulotyöstä voi tulla pysyvä tilanne (ks. esim. Strömmer, 2017). Samalla tavalla väliaikaisen vierastyöläisen eteneminen työssä esimerkiksi palkkauksen suhteen voi hankaloitua, jos mahdollisuutta kielitaidon kehittämiseen ei ole.

Svennevig (2017) on tehnyt keskustelunanalyyttisen tutkimuksen kielen oppimisen mahdollisuuksista rakennusalan vuorovaikutustilanteissa Norjassa puolalaisen vierastyöntekijän näkökulmasta. Hänen analyysinsa keskittyy hetkiin, joissa tämä norjaa oppiva työntekijä itse kysyy tiettyjen sanojen norjankielistä asua työtovereiltaan. Aineisto on peräisin samoista autenttisista työtilanteista, joita myös Kraft (2017) on tutkinut, ja Svennevigin analyysi todentaa sen Kraftin esittämän näkökulman, että kielen oppiminen on yksilön vastuulla. Svennevigin analyysi keskittyy aktiivisesti kielen oppimiseen suuntautuvaan norja toisena kielenä -puhujaan ja 
havainnollistaa, että kieleen keskittyvät hetket motivoituvat työhön liittyvistä teemoista ja kytkeytyvät usein konkreettisiin näkyvillä oleviin materiaalisiin objekteihin.

\section{AINEISTO JA MENETELMÄ}

Aineistonkeruutamme ohjasi tavoite saada selville, millaisia rakennusalan työtehtäviin liittyvät kielenkäyttötilanteet ovat. Saimme aikuiskoulutuskeskuksen rakennusalan koulutuspäälliköltä, opettajilta ja opiskelijoilta luvan seurata heitä viikon ajan ja samalla videoida ja äänittää työtilanteita. Nauhoituksemme keskittyivät opiskelijoiden vuorovaikutustilanteisiin, ja erityisesti seurasimme kotoutumiskoulutuksessa olevia opiskelijoita, joiden tavoitteena oli siis oppia kieltä samalla kun he kartuttivat rakennusalan kokemustaan. Nauhoitimme kaikki sellaiset työhön liittyvät vuorovaikutustilanteet, jotka oli mahdollista nauhoittaa yhden tutkijan voimin. Osalle opiskelijoista annoimme ääninauhurin taskuun. Video- ja ääninauhoitukset on litteroitu keskustelunanalyyttisten litterointikonventioiden mukaisesti (ks. Seppänen, 1997)². Litterointikonventiot on esitelty liitteessä 1 . Osan videoaineistosta olemme litteroineet tarkasti myös osallistujien multimodaalisen toiminnan näkökulmasta, koska fyysisessä työssä tekeminen ja siihen kytkeytyvät eleet sekä materiaalinen ympäristö ovat olennaisessa osassa vuorovaikutuksen rakentumisessa. Kehollisen toiminnan litterointiin on käytetty Mondadan kehittämää merkintätapaa (ks. Mondada, n.d.).

Aineiston analyysin menetelmä on multimodaalinen keskustelunanalyysi (ks. Goodwin 2000; Mondada, 2014, 2016). Erittelemme siis vuorovaikutustilanteiden kielenkäyttöä vuoro vuorolta ja kiinnitämme

2 Kiitämme projektimme tutkimusavustajaa FM Anna-Kaisa Jokipohjaa huolellisesta avusta litteraattien valmistamisessa. huomiota myös osallistujien kehollisen toiminnan yksityiskohtiin sekä niihin materiaalisiin resursseihin sekä siihen fyysiseen tilaan ja ympäristöön, jotka ovat meneillään olevan vuorovaikutuksen ja yhteisen ymmärryksen rakentumisen näkökulmasta olennaisia. Näiden keinojen erittelyn kautta on mahdollista vastata kysymykseen siitä, millaista kieltä rakennusalan työtehtävissä tämän aineiston valossa tyypillisesti käytetään ja tarvitaan.

Vaikka seurasimme työtilanteita nimenomaan oppilaitoksessa, kielenkäytön näkökulmasta tilanteet ovat uskoaksemme samankaltaisia kuin todellisen työelämän tilanteet. Tämä olettamuksemme kaipaa tuekseen vielä tutkimusta todellisista työtilanteista, mutta sen perusteena on havainto siitä, että aikuiskoulutuskeskuksessa opiskelijat toimivat itsenäisesti ja tekevät projektejaan joko yksin tai pienissä ryhmissä työtehtävien luonteesta riippuen - samoin kuin oletettavasti työelämässä. Opettaja ei siis ole koko ajan läsnä ohjaamassa toimintaa, vaan opettajat ovat paikalla ja auttavat vain tarvittaessa. Seurantajakson aikana opettajien asiantuntemukseen turvauduttiin tyypillisimmin työvaiheiden siirtymäkohdissa eli silloin, kun yksi vaihe oli saatu valmiiksi ja oli aika aloittaa seuraava. Näissä kohdissa opettaja saattoi arvioida työn jälkeä ja antaa ohjeita seuraavaan vaiheeseen.

Rakennusalan opiskelijat olivat kaikki aikuisia. Osa oli suomea äidinkielenään puhuvia ja osa kotoutumiskoulutuksen opiskelijoita, jotka rakennusalan sisältöjen lisäksi olivat siis paikalla oppimassa myös suomen kieltä. Työtehtävät rakennusalalla vaihtelevat, ja opiskelijoiden on mahdollista erikoistua esimerkiksi muuraukseen, laatoitukseen tai rakentamiseen. Myös kielenkäytön ja vuorovaikutuksen näkökulmasta työtehtävät eroavat toisistaan. Muurauspuolella opiskelijat kuuntelivat havainnointiviikkomme aluksi melko pitkään opettajan ohjeistusta ja perehdytystä työn eri vaiheisiin ja heille tarjoutui myös mahdolli- 
suus kysyä tarkennuksia. Loppuviikon ajan he keskittyivät konkreettiseen tekemiseen, mikä oli pääosin yksilöllistä työtä. Puhetilanteita ei enää juuri tarjoutunut lyhyitä ohjeistuksia lukuun ottamatta. Myös laatoitusta opiskelevat tekivät omaa laatoitusprojektiaan lähinnä yksin ja olivat vuorovaikutuksessa opettajan kanssa työtehtävien siirtymäkohdissa tai ongelmien tai kysymysten esiin noustessa. Rakentajat taas rakensivat puuvajaa yhteistyössä, ja tässä työssä vuorovaikutus työkavereiden kanssa oli nähdäksemme koko projektin onnistumisen edellytys. Aineistostamme melko suuri osa keskittyy rakennustyöhön juuri siitä syystä, että aineistonkeruun aikaisten havaintojemme perusteella se sisälsi runsaasti vuorovaikutusta ja oli siksi kielenkäytön näkökulmasta kiinnostava.

\section{ANALYYSI: OHJAILEVAA TOIMINTAA MATERIAALISESTI MONIPUOLISISSA YMPÄRISTÖISSÄ}

Analysoimme seuraavaksi näytteitä aineistostamme. Olemme valinneet näytteet niin, että ne havainnollistavat aineistossamme toistuvia ja tyypillisiä vuorovaikutustilanteita.

Aineistonäytteissämme keskeinen puhetoiminta on direktiivistä: niissä pyydetään, ohjataan ja ohjeistetaan. Näytteet ovat kuitenkin peräisin materiaalisesti ja tavoitteiltaan erilaisista työtilanteista, ja niissä havainnollistuu selvästi ohjailevan toiminnan kytkeytyminen osaksi niitä fyysisiä aktiviteetteja ja tehtäviä, joita osallistujat ovat tekemässä.

Ensimmäinen näyte havainnollistaa tilannetta, jossa laatoitusalan opettaja antaa suomea toisena kielenään käyttävälle opiskelijalle ohjeita työn seuraavaan vaiheeseen. Esimerkit kaksi ja kolme ovat peräisin vajanrakennusprojektista, jossa kaksi suomea toisena kielenään puhuvaa opiskelijaa rakentaa vajaa yhdessä. Työn onnistumiseksi heidän on pyydettävä toisiltaan apua esimerkiksi mittaamiseen ja eri työkalujen etsimiseen ja hakemiseen. Neljäs esimerkki havainnollistaa harvinaisempaa tilannetta, jossa opiskelijoiden huomio kiinnittyy kielen käyttämiseen ja opetteluun.

\subsection{Opettajan ohjaileva toiminta laatoitusopastuksessa}

Esimerkki 1 on tilanteesta, jossa opettaja (OPE) arvioi opiskelijan (Karim) tekemää laatoitettavan lattia-alueen pohjustustyötä ja antaa hänelle ohjeita seuraavaan työvaiheeseen. Esimerkki havainnollistaa useita aineistomme vuorovaikutustilanteille tyypillisiä kielenkäytön piirteitä. Pääasiallinen puhetoiminta tilanteessa on ohjailevaa: opettaja kertoo, miten työssä on edettävä ja miksi. Puhetoiminta kytkeytyy hyvin kiinteästi fyysiseen ja materiaaliseen ympäristöön, ja tilanteessa merkitykselliset työvälineet ovat olennaisessa osassa merkityksen rakentamisessa. Ohjeistuksessa käytetään rakennusalalle tyypillistä erikoissanastoa työvälineisiin viitattaessa (passi, rabina).

Ennen rivin 1 alkua opettaja on ollut kumartuneena lattialla ja arvioinut sen tasaisuutta vatupassin avulla. Rivin 1 aikana hän nousee seisomaan, katsoo kohti opiskelijaa ja kertoo, että seuraavassa työvaiheessa lattia täytyy hioa täysin sileäksi. 
Esimerkki 1a. Laatoitusohjeistus

+ opettajan eleet

* Karimin eleet

\#kuvan sijoittuminen suhteessa puheeseen

$01 \mathrm{OPE}$ : täytyy hioo? (.) $\begin{aligned}+ & \text { rahinalla ( - ) (.) } \\ + & \text { ele oikealla kädellä: hiomisliike } \\ & \text { rinnan korkeudella }\end{aligned}$

02
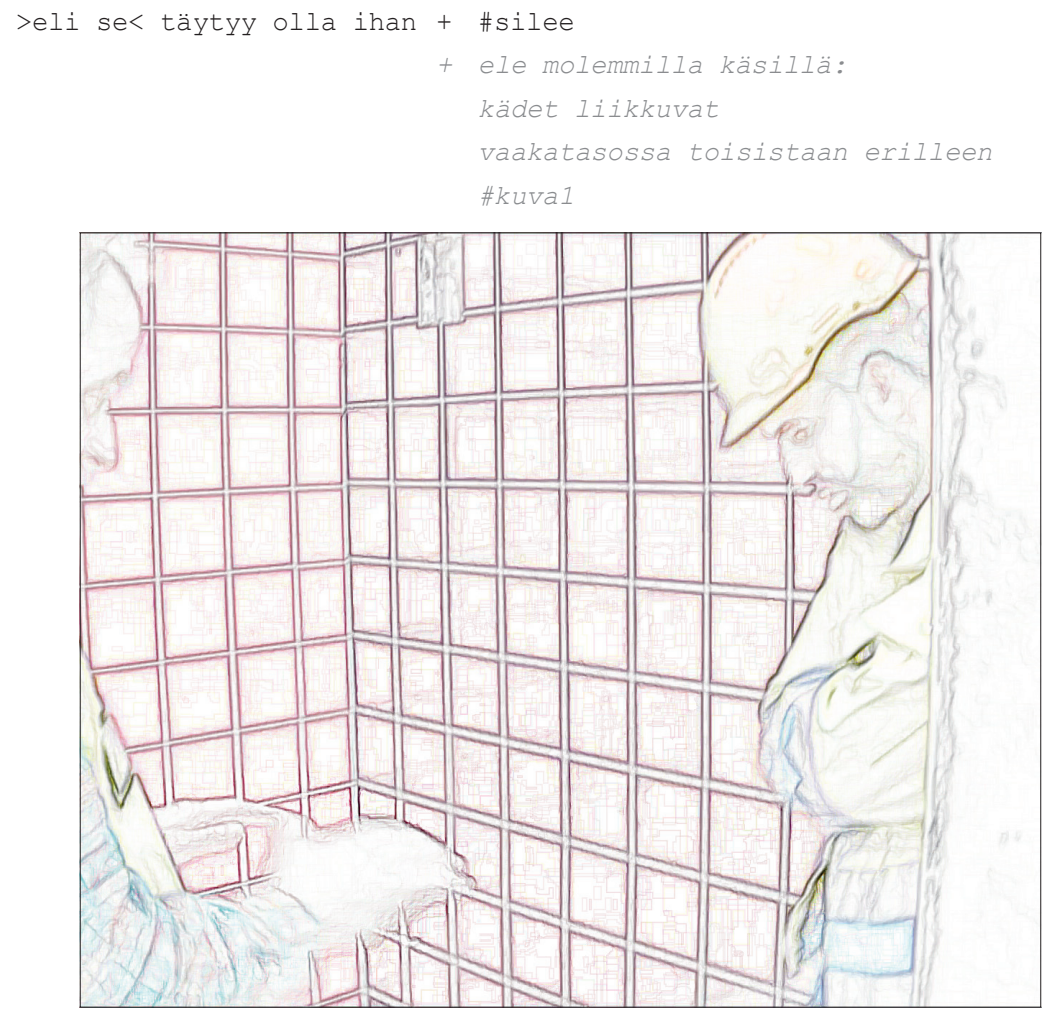

$04 \mathrm{KAR}:{ }^{\circ} \mathrm{okei}{ }^{\circ}$

06 OPE: jOO,

07 KAR: * ( - )

*ele vasemmalla kädellä: osoitus kohtia lattiaa

08 OPE: kaikki ihan silee

09 $(+2.2)$

ope: +kumartuu kohti lattiaa ja asettelee vatupassia lattialla 
10 OPE: +>niinku< (.) kokeileppas tolla \#itte tolla (.) +nousee seisomaan ja osoittaa noustessaan kohti vatupassia molemmilla käsillä

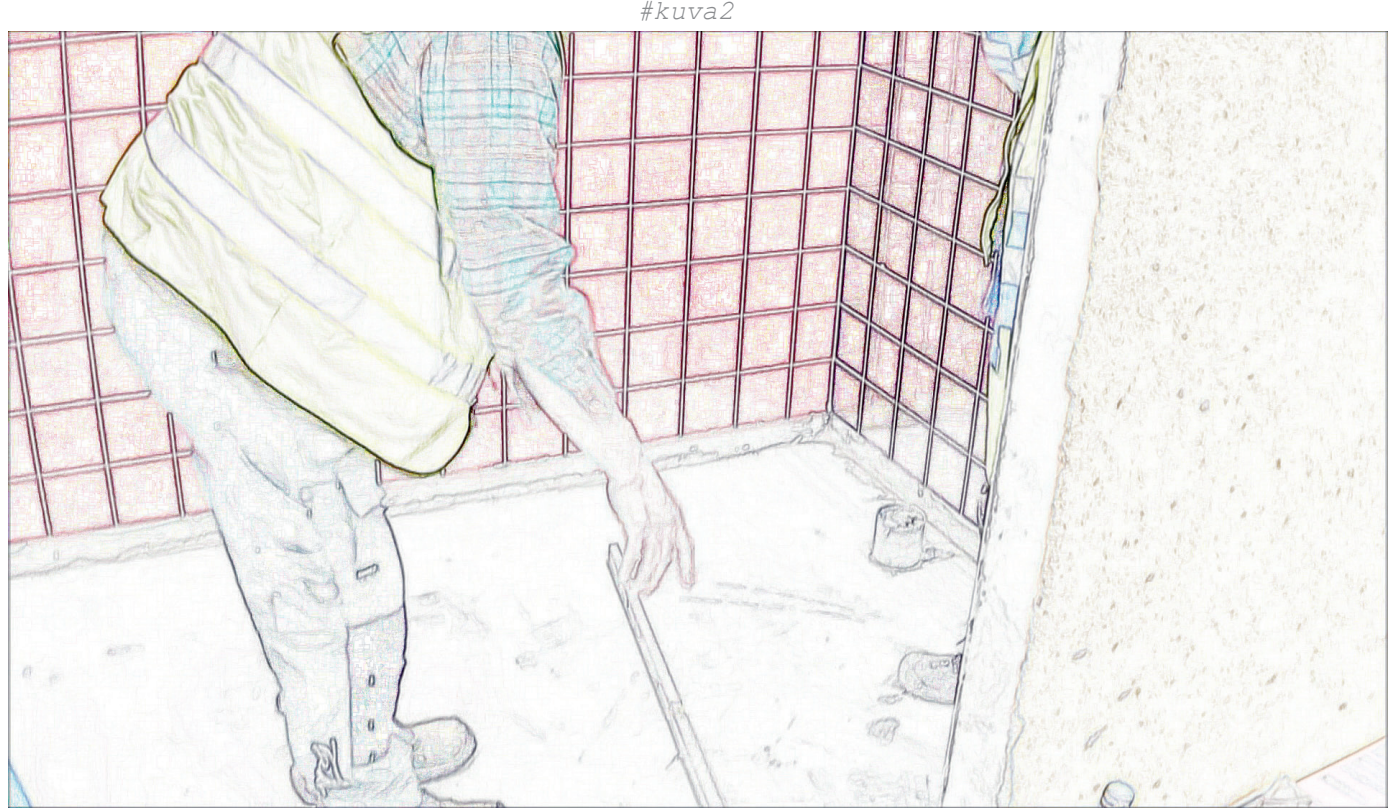

11 passilla kokeile sitä, * (0.6) kar:

* kumartuu kohti lattiaa ja asettelee vatupassia oikealla kädellään-> se keikkuu siin, (0.8)

+ottaa askeleita kohtia KARia ja asettelee myös vatupassia->

14 OPE: niin (.) kato (.) ( - ) niin tos om +(patti)\#*

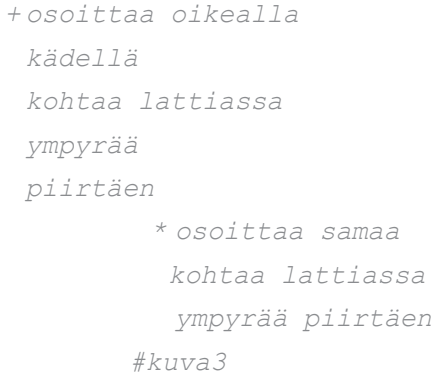




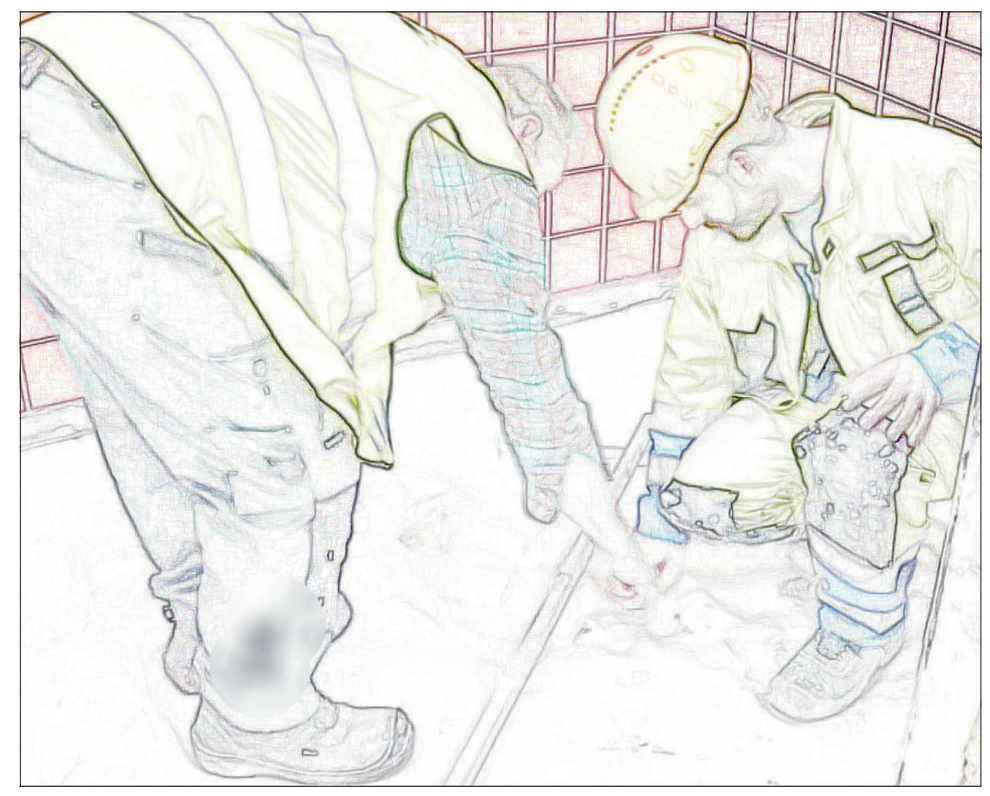

$15 \mathrm{KAR}: *(--)$

*nousee seisomaan ja siirtyy hieman toiseen kohtaan mittamaan

16 OPE: joo ja sitte onko mulalla

Opettajan ensimmäinen ohjevuoro rakentuu kahdesta vuoron rakenneyksiköstä. Ensimmäinen rakentuu yksipersoonaisen täytyyverbin ympärille: täytyy hioo rabinalla (r. 1). Toinen on nesessiivirakenne, joka täsmentää, millaista lopputulosta hiomisella tavoitellaan: sen (eli lattian) täytyy olla ihan silee (r. 2). Kaikkiaan opettajan ohjeistus on siis kielellisesti passiivimainen. Hän ei kohdista pyyntöjään suoraan Karimille eikä ohjeista tätä toimimaan tietyllä tavalla, vaan rakentaa ohjeistuksensa yleisemmäksi kuvaukseksi siitä, mitä tilanteessa on tehtävä. Ohjeistuksessa opettajan eleet ovat olennaisia: rahinaan viitatessaan hän tekee oikealla kädellään hiomista havainnollistavan eleen. Sileä-adjektiivin yhteydessä hän levittää hieman rinnan alapuolella olevia käsiään toisistaan erilleen vaakasuorassa (ks. kuva 1). Tämä ele havainnollistaa sileää ja tasaista lattiapintaa.

Karim ottaa ohjeistuksen vastaan hiljaisella okei-partikkelilla (r. 4) sekä osoittamalla vasemmalla kädellään lattiaa kohti (r. 7). Tämä toiminta ei vielä osoita, onko Karim ymmärtänyt, miten tilanteessa tulisi toimia. Seuraavaksi opettaja kumartuu kohti lattiaa, asetteleevatupassia lattian pinnassa (r. 9) ja ohjeistaa sitten Karimia myös kokeilemaan (r. 10). Tämän ohjeistuksen yhteydessä hän elehtii kohti vatupassia molemmilla käsillään (kuva 2) ja viittaa siihen sanalla passi (r. 11). Ohjeistuksen verbit ovat imperatiivimuotoisia, ja niistä ensimmäiseen yhdistyy $p A$-liitepartikkeli, joka tekee imperatiivista ehdotuksen kaltaisen (ks. VISK $\$ 835)$. Kun Karim ryhtyy itse tutkimaan vatupassilla lattian sileyttä, opettaja sanoittaa havaintojaan: vatupassi keikkuu (r. 12). Hän kumartuu jälleen kohti lattiaa ja havainnollistaa vatupassin avulla lattiassa olevaa epätasaista kohtaa (r. 14). Videolta ei ole mahdollista kuulla selvästi, millä sanalla opettaja tähän epätasaiseen kohtaan viittaa, 
mutta hän osoittaa kohtaa oikealla kädellään piirtäen sen yläpuolella ympyrää. Kyseinen kohta on siis ympyrän muotoinen. Karim osoittaa ymmärrystään toistamalla opettajan osoittavan ja ympyrää esittävän eleen (r. 14, kuva 3) (eleiden toistosta ymmärrystä osoittamassa Eskildsen \& Wagner, 2013).

Lattian konkreettinen tutkiminen vatupassin avulla yhdessä nostaa siis siinä olevat epä- tasaisuudet huomion kohteeksi ja tuo toimintana perusteluja sille, miksi lattia on hiottava. Ohjeistus ei siis toteudu tässä pelkästään kielellisesti, vaan lattian konkreettinen tutkiminen yhdessä on osa sitä. Karim jatkaa lattian tutkimista ja saatuaan sen päätökseen ryhtyy sanoittamaan, mitä hän seuraavaksi aikoo tehdä (esim. 1b, r. 1).

Esimerkki 1 b. Laatoituksen seuraavat työnvaiheet

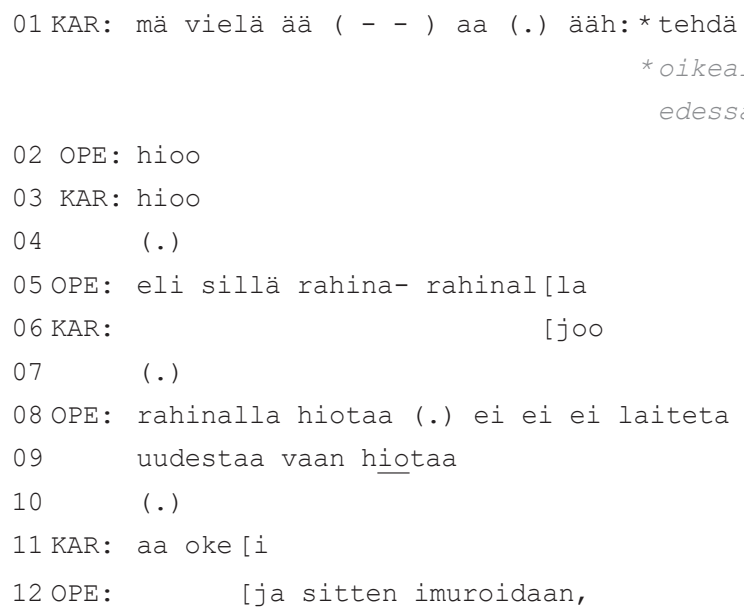

Oman toiminnan kielentäminen on Karimille haastavaa, mikä näkyy esimerkiksi hänen vuoronsa epäröintiäänteissä (r. 1). Vuorossa on myös epäselvää aineista, mutta se päättyy selvästi artikuloituun tehdä-verbiin, joka aikana Karin tekee vasemmalla kädellään laajan eleen vartalon edessä. Tämä ele kuvaa samalla tavalla sileää pintaa kuin opettajan aikaisempi sileä-adjektiiviin yhdistynyt ele, ja opettaja reagoi Karimin vuoroon tuottamalla hioa-verbin (r. 2), jonka Karim toistaa (r. 3), ja jatkamalla sitten passiivimuotoisella kuvauksella siitä, mitä seuraavaksi tehdään: hiotaan ja imuroidaan.

Kaiken kaikkiaan esimerkki 1 havainnollistaa keskeisiä aineistomme vuorovaikutus- tilanteille tyypillisiä piirteitä ja erityisesti sitä, miten ohjeistuksessa verbaalinen modaliteetti toimii yhdessä tilanteessa olennaisten materiaalisten resurssien ja konkreettisen toiminnan kanssa. Puhuttuja vuorojen rakenneyksiköitä on vaikea täysin ymmärtää ilman käsitystä siitä, millainen työvaihe on kyseessä ja millaisessa materiaalisessa ympäristössä. Erityisesti eleissä ja muussa osallistujien kehollisessa toiminnassa tämä näkyy selvästi: eleet kytkeytyvät materiaaliseen ympäristöön eivätkä ole sellaisenaan ymmärrettävissä vain osallistujien käsien liikkeitä havainnoimalla (environmentally coupled gestures, ks. Goodwin, 2007). Kaiken kaikkiaan osallistujien puhe ja eleet yhdessä muodostavat merkityksiä, 
joita kumpikaan modaliteetti (kielellinen tai kehollinen) ei yksinään pysty välittämään: kieli ja materiaaliseen ympäristöön kytkeytyvä toiminta siis täsmentävät toisiaan ja tuovat lisämerkityksiä.

\subsection{Kakkoskielisten pubujien keskinäinen ohjaileva toiminta}

Esimerkit 2 ja 3 ovat rakennusprojektista, jossa suomea toisena kielenä puhuvat opiskelijat (Ralf ja Alan) rakentavat yhdessä puuvajaa. He organisoivat keskinäisen työnjakonsa tavallisimmin siten, että Ralf oli aktiivinen rakennustyön tekijä (ja kiinnitti lautoja, rakensi kattotuoleja jne.), kun taas Alan teki enemmän avustavia tehtäviä esimerkiksi hakien Ralfille kulloinkin tarvittavia työvälineitä. Usein vajanrakennukseen liittyvät työtehtävät etenivät pitkänkin aikaa ilman puhetta. Erityisesti tilanteissa, joissa osallistujat olivat saaneet tietyn työvaiheen käyntiin ja heillä vaikutti olevan yhteinen jaettu käsi- tys siitä, miten työ etenee, puhetta ei tarvittu. Toisaalta rakennustyöhön liittyy toistuvasti myös tilanteita, joissa seuraavasta vaiheesta on neuvoteltava tai joissa osallistujilla ei eri syistä ole jaettua käsitystä siitä, mitä täsmällisesti ottaen seuraavaksi täytyy tehdä. Esimerkit 2 ja 3 havainnollistavat tällaisia tilanteita. Molemmissa Ralf pyytää Alania etsimään tai ojentamaan tietyn työvälineen, jota tarvitaan projektin seuraavassa vaiheessa.

Ensimmäisessä esimerkissä Ralfja Alan ovat asettamassa vajan kattotuoleja kohdilleen. Ralf seisoo tikkailla vajan seinän vieressä ja käsittelee kattotuoleja. Alan seisoo hänen vieressään havainnoiden työtä. Esimerkin kahdella ensimmäisellä rivillä Ralf kielellistää kattotuolin kiinnittämistä hankaloittavan ongelman: kattorakenteissa on naula, joka estää lautojen kiinnittämisen juuri haluttuun kohtaan. Tämä johtaa neuvotteluun, jonka aikana Ralf pyytää Alania ojentamaan hänelle naulan poistamiseen tarvittavan työkalun (r. 15).

Esimerkki 2. Voisitko antaa mulle

\section{+ RALin katse \\ * RALin eleet \\ $\varnothing$ ALAN eleet}

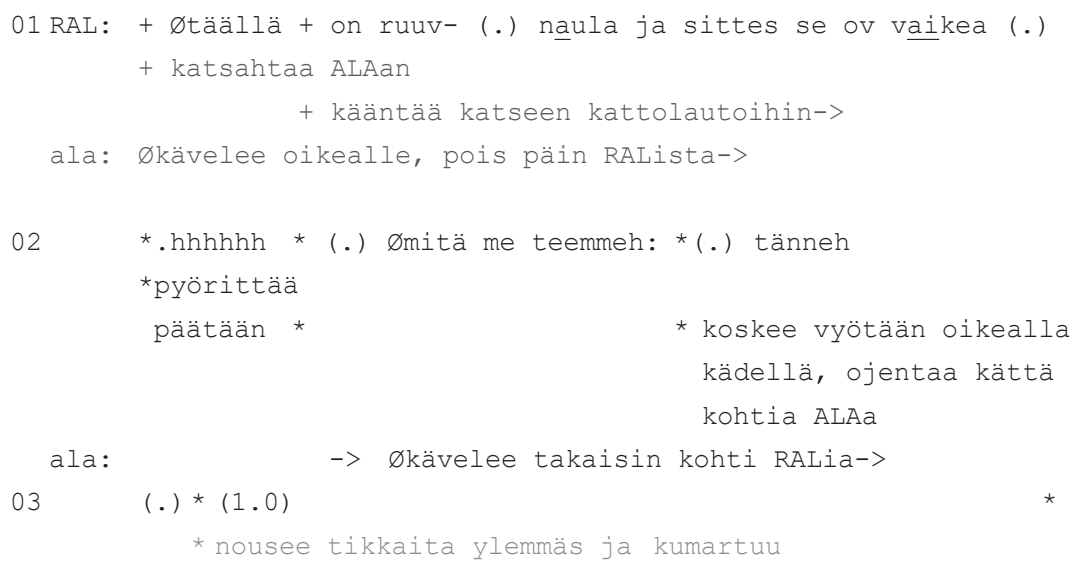




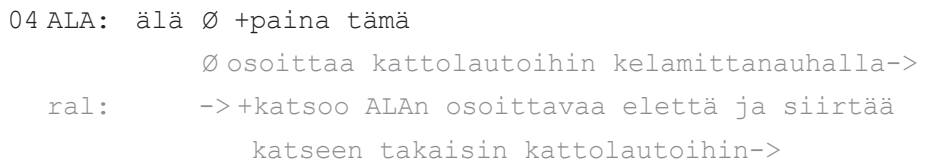

08 ALA: >ruuvi?<

09 RAL: +ei naula $[+($.$) tarvii poistaa$

->+katse ALAan +katse kattolautoihin ->

10 ALA: [naula

11

(.)

12 RAL : .phhh

13 ALA: pala pois

$14 \quad($.

15 RAL: +.hhh (.) hhh voi *sitko antaa mulle \#*+

->+ katse alas oikealle ja sitten vasemmalle, sitten kattolautoihin->
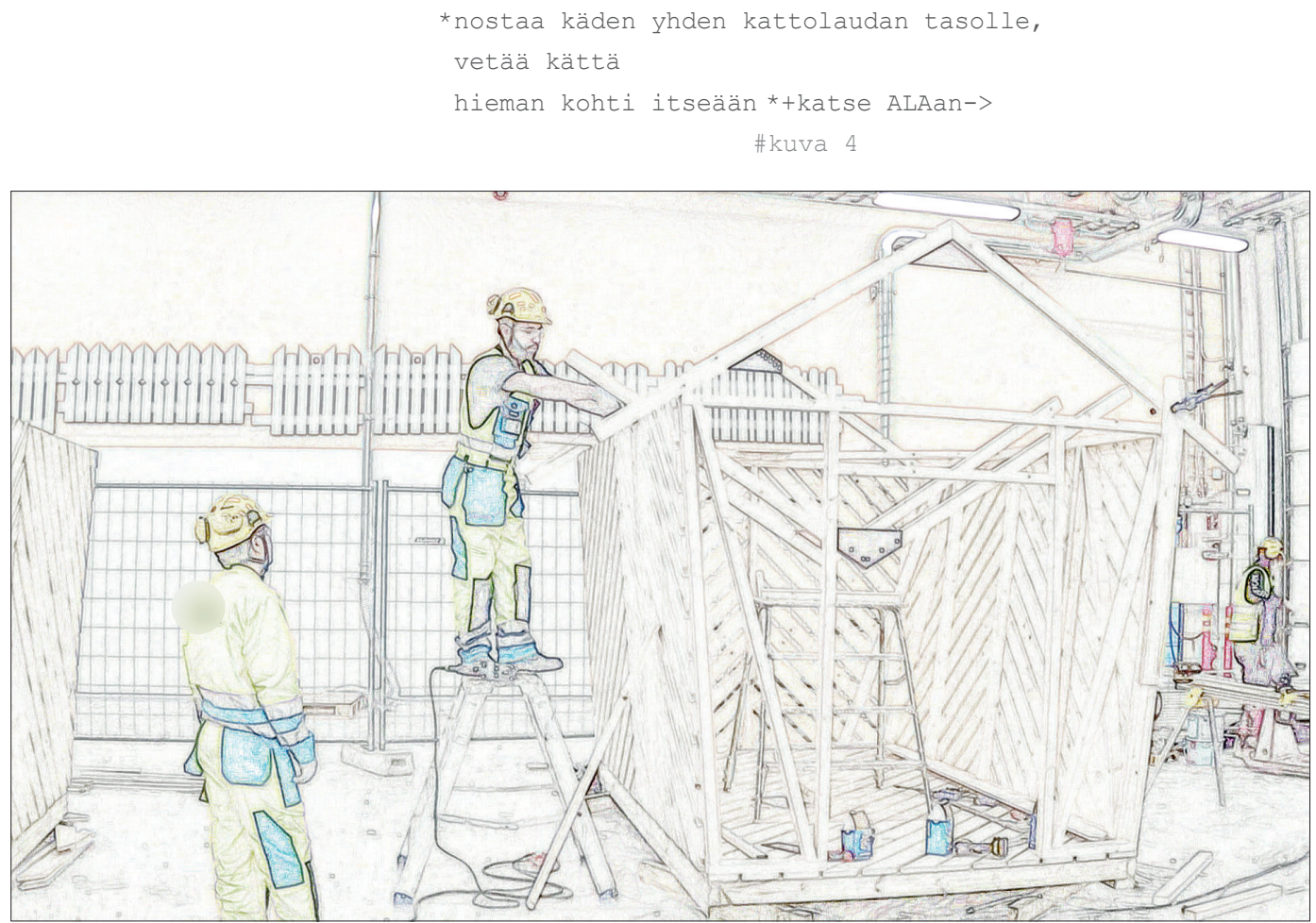


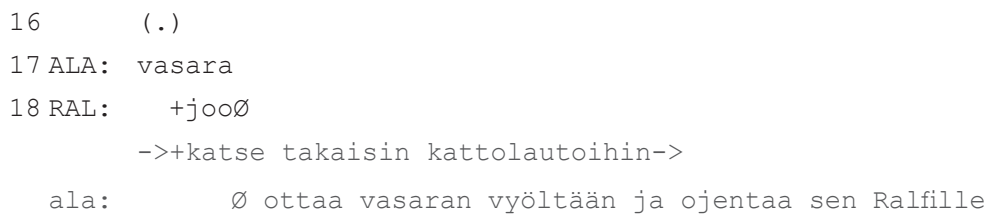

Esimerkki havainnollistaa siis tilannetta, jossa kieltä tarvitaan työssä esille tulleesta ongelmasta neuvotteluun ja sen selvittämiseen, miten ongelma olisi parasta ratkaista. Keskitymme analyysissamme erityisesti Ralfin pyyntövuoroon (r. 15). Vuoro alkaa verbaalisesti voisitko antaa mulle -rakenteella. Tämä rakenne jää tunnistettavasti kesken, sillä siinä ei verbalisoida infinitiivirakenteen objektia eli Ralf ei sano, minkä työkalun hän toivoo Alanin hänelle antavan. Sen sijaan hän jatkaa verbaalisen vuoron päättymisen jälkeen elehdintää: hän nostaa oikean kätensä kattolautojen korkeudelle ja vetää kättä itseään kohti koukistaen samalla etu- ja keskisormeaan (ks. kuva 4). Eleen päättymisen jälkeen hän kääntää katseensa Alaniin, joka pienen tauon jälkeen sanoo "vasara" (r. 17). Alan siis verbalisoi Ralfin vuorosta puuttuvan sanan, jota Ralf esitti eleellä. Tämä verbalisointi on kiinnostava ainakin kahdesta näkökulmasta. Ensinnäkin se osoittaa, että Ralfin hybridi vuoro on ollut Alanille ymmärrettävä; hän on ymmärtänyt, mitä työkalua Ralf on pyytämässä. Toiseksi työkalun nimen verbalisoiminen toimii kuitenkin myös ikään kuin täydennyksenä ja jatkona Ralfin vuorolle ja näin osoittaa osallistujien suuntautumista verbaalisen modaliteetin tärkeyteen. Vaikka siis yhteinen ymmärrys on jo olemassa, on tärkeää sanoa äänen pyydetyn työkalun nimi. Seuraavassa vuorossa Ralf vahvistaa, että hän pyytää nimenomaan vasaraa, ja Alan ottaa vasaran vyöltään ja ojentaa sen Ralfille, joka ryhtyy irrottamaan ongelmanaulaa kattolaudoista.

Ralfin pyyntö toteutuu tässä siis hybridinä vuorona, jonka alku on verbaalinen mutta joka viedään loppuun kehollisesti eleen avulla (ks. myös Olsher, 2004; Mori \& Hyashi, 2006). Analyysin kannalta olennainen kysymys on, miksi hän tuottaa pyyntönsä tässä kohtaa juuri näin rakennetun vuoron avulla. Yksi mahdollisuus on ajatella, että Ralf saattaa vuoronsa loppuun eleellä kompensoidakseen puutteita sanavarastossaan: ehkä vasarasana ei ole vielä niin vakiintunut osa hänen sanavarastoaan, että hän muistaisi sen heti tarpeen tullen. Toisaalta muualta aineistostamme näkyy, että Ralf käyttää vasara-sanaa myös ilman ongelmia. Kompensointiselitystä todennäköisemmältä näyttääkin se, että hybridin vuoron käytölle on tilanteisempi selitys ja motivaatio. Se toiminta, johon Ralf työkalua tässä pyytää, ei ole vasaran ensisijainen käyttötapa. Myöskään hänen tekemänsä ele ei ole konventionaalinen vasara-ele, vaan havainnollistaa jonkin pois vetämistä ja liittyy ensisijaisesti siihen toimintaan, johon hän pyytämäänsä työkalua tarvitsee. Kun Ralf tekee eleen, joka luonnehtii, mitä hän aikoo pyytämällään työkalulla tehdä, hän tulee samalla demonstroineeksi työkumppanilleen näkemyksensä siitä, miten hänen mielestään tilanteessa kannattaa toimia. Tämä voi olla erityisen olennaista tässä tilanteessa, jossa Ralfin ja Alanin käsitykset tilanteen ratkaisemisesta näyttävät eroavan toisistaan. Edellä Alan on juuri esittänyt, että tilanteen voisi ratkaista ottamalla naulasta palan pois (r. 13). Ele on siis tässä tehokas tapa saattaa pyyntö loppuun ja samanaikaisesti kommunikoida Alanille, miten Ralf aikoo tilanteessa edetä.

Myös esimerkki 3 havainnollistaa hybri- 
diä pyyntövuoroa, jossa ele kuvaa pyydettyä työkalua. Esimerkki on tilanteesta, jossa Ralf on kiinnittämässä kulmarautaa kattorakenteisiin. Esimerkin alussa Alan ojentaa Ralfille ruuvin ja luonnehtii ruuvia paremmaksi kuin joitakin toisenlaisia ruuveja (r. 1). Ralf ottaa ruuvin vastaan samanmielisyyttä osoittaen ( $\mathrm{r}$. 3) ja ryhtyy tämän jälkeen asettelemaan ruuvia kulmarautaan. Hybridi pyyntövuoro on rivillä viisi.

Esimerkki 3. Missä on ruuvikone

$$
\begin{aligned}
& \text { + RALin katse } \\
& { }^{*} \text { RALin eleet } \\
& \varnothing \text { ALAn eleet }
\end{aligned}
$$

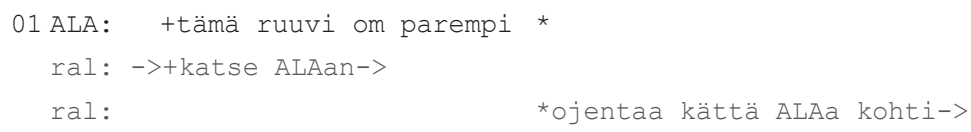

05 RAL: missä on: *\# $\varnothing$

->*nostaa oikeaa kättään kattolaudan päällä,

vetää etusormea itseään kohti

ala: Øottaa kaksi askelta taakse päin-> \#kuva 5

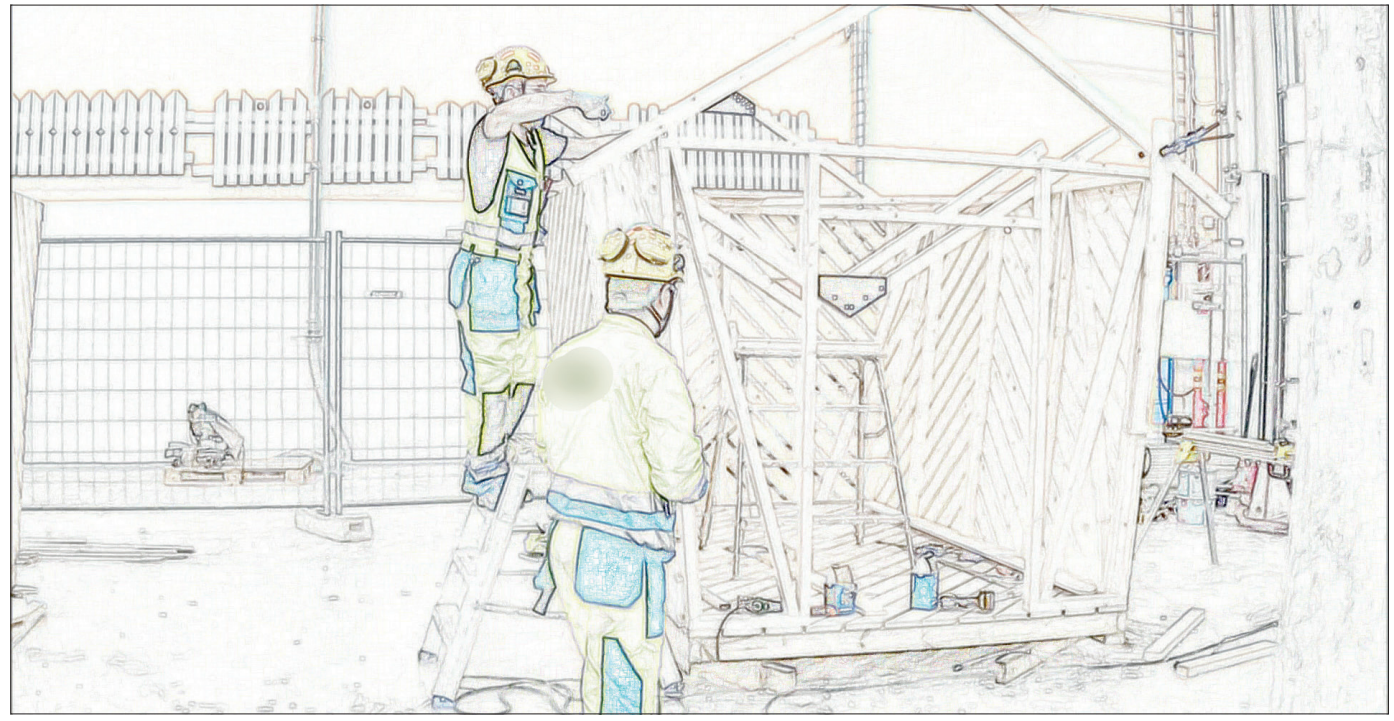




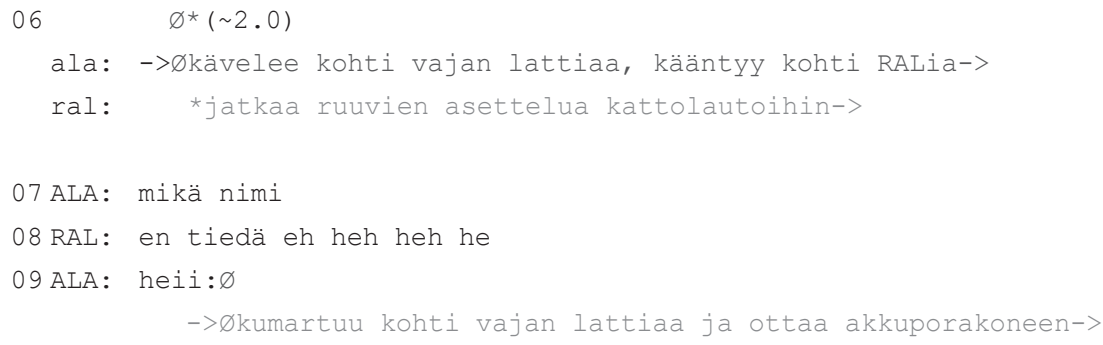

17 ALA: ruuvikone

18 RAL: ei oo * eh heh [ heh

-> * ottaa koneen ALAlta ja kääntyy takaisin kohti kattolautoja->

19 ALA:

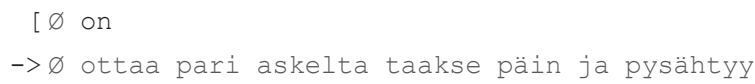


Vuoro alkaa kysymyssanalla missä ja päättyy eleeseen, jonka aikana Ralfin oikea käsi on kattolautojen korkeudella ja hän vetää etusormea itseään kohti (kuva 5). Jo ennen kuin Ralf on ehtinyt saattaa vuoron ja eleensä päätökseen, Alan ottaa kaksi askelta taaksepäin ja lähtee sitten kävelemään kohti vajan lattiaa. Tämä liikkumisen aloittaminen vielä Ralfin vuoron ollessa kesken osoittaa, että Alan tietää todennäköisesti jo ennen elettä, mitä Ralf on pyytämässä. Hän on seurannut Ralfin työskentelyä ja on näin ollen todennäköisesti hyvin perillä siitä, mikä seuraava työvaihe tulee olemaan.

Alan kuitenkin keskeyttää liikkeensä ennen kuin hän kumartuu ottamaan työkalua vajan lattialta, kääntyy kohti Ralfia ja kysyy työkalun nimeä (r. 7). Samalla tavalla kuin edellisessä esimerkissä myös tässä hybridi vuoro on siis ollut ymmärrettävä, mutta Alan kuitenkin suuntautuu myös työkalun nimen tietämisen tärkeyteen. Ralf vastaa Alanin kysymykseen naureskellen ja todeten, että hän ei tiedä työkalun nimeä. Kun Alan sitten kävelee Ralfin luo akkuporakone kädessään, Ralf kysyy saman kysymyksen tältä. Molemminpuolinen kysely saa jo tässä kiusoittelun sävyä, ja tämä sävy vahvistuu sekvenssin edetessä. Alan vastaa kysymykseen sanalla ruwvi (r. 15) ja Ralf toistaa sanan seuraavassa vuorossa nousevalla sävelkululla ja liittäen siihen kone-edusosan (r. 16). Tämä Ralfin vuoro siis tarkistaa, tarkoittiko Alan, että koneen nimi olisi ruuvikone. Alan vahvistaa sanan oikeaksi toistamalla sen seuraavassa vuorossa (ks. Thompson, Fox \& Couper-Kuhlen, 2015), mutta Ralf ei kuitenkaan usko tähän, vaan toteaa nauraen, että sana ei ole oikea (r. 18-20). Työ jatkuu, ja Alan toistelee sanoja (r. 22). Kun Ralf on saanut ruuvin kiinnitettyä kulmarautaan, hän sanoo: "ei ole mitä sä haluat". Analysoimme tämän vuoron mahdollisesti viestivän, että Alan ei voi Ralfin mielestä päättää, mikä kyseisen työkalun nimi on.
Mahdollista on myös se, että Ralf on tunnistanut ruuvikoneen vääräksi nimitykseksi, vaikka ei tiedäkään, mikä työkalun oikea nimi on. Alanin vuoro rivillä 26 päättää sekvenssin. Siinä hän viittaa tarpeeseen oppia rakennuksella tarvittavien työkalujen nimiä. Vuoro osoittaa, että hän on tunnistanut motivaationsa oppia rakennusalalla tarvittavaa erityissanastoa.

Esimerkki 3 siis havainnollisti tilannetta, jossa näkyivät samat rakennusalan kielenkäyttötilanteille ominaiset piirteet kuin kahdessa aikaisemmassa esimerkissä: toiminta on ohjailevaa ja merkityksiä rakennetaan kielen, eleiden ja materiaalisten resurssien avulla. Tämän lisäksi tilanteessa kuitenkin avautuu mahdollisuus kielestä keskusteluun, ja osallistujat puhuvat käyttämänsä työkalun nimestä. Kielestä puhuminen tapahtuu meneillään olevan toiminnan lomassa eikä keskustelussa varsinaisesti päästä yhteisymmärrykseen, koska Ralf ei hyväksy Alanin ehdottamaa sanaa työkalun nimeksi. Tällaisessa tilanteessa kielen oppimista tukisi esimerkiksi se, että mukana olisi suomea enemmän osaavia työkavereita, jotka toimisivat kielellisinä asiantuntijoina, tai se, että työvälineiden nimet olisivat näkyvillä. Esimerkki 4 havainnollistaa tätä tematiikkaa vielä selvemmin. Siinä Ralf ja Alan tukeutuvat opettajan kielelliseen apuun, ja lopulta Ralf kirjoittaa muistiin sanan, jota hän on esimerkin havainnollistamassa tilanteessa tarvinnut.

\subsection{Kulmarautoja etsimässä: kieli buomion kobteena}

Esimerkki $4^{3}$ liittyy tilanteeseen, jossa Ralf etsii kulmarautoja kattotuolien kiinnittämistä varten. Esimerkki koostuu useammasta sekvenssistä, joiden aikana kulmarauta-sanaa ensin haetaan, sitten käytetään ja lopuksi muis-

3 Tämän esimerkin olemme litteroineet pääasiassa vain puheen perusteella, koska kaikkia esimerkin osia ei ole videonauhalla. 
tellaan. Esimerkin alussa Ralf kävelee kohti rakenteilla olevan vajan luona työskentele- vää Alania ja kysyy, muistaako tämä, minkä niminen on se tarvike, jota hän on etsimässä.

\section{Esimerkki 4a. Kulmarauta-sanan etsiminen}

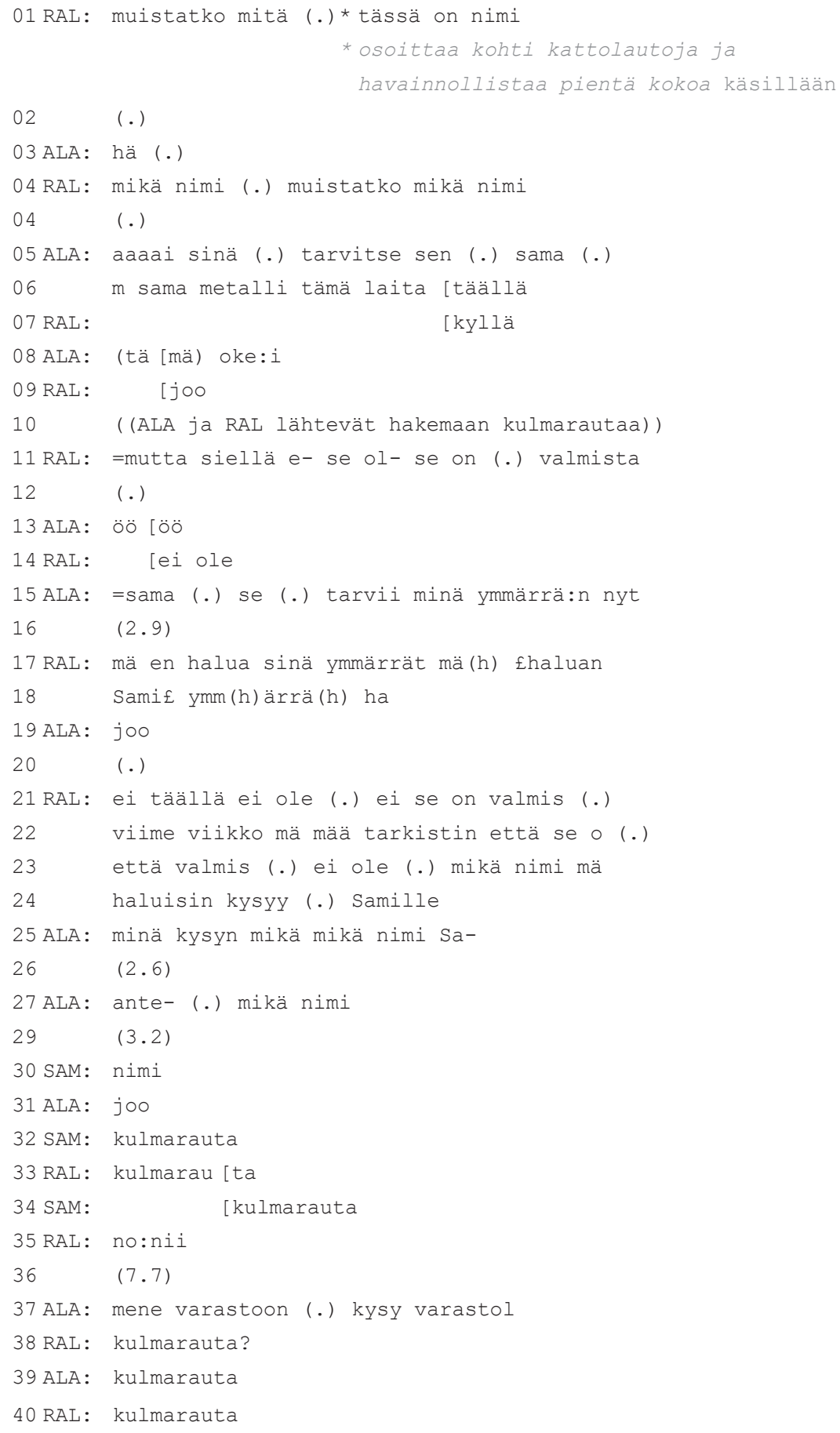


Kysyessään Alanilta kulmaraudan nimeä Ralf samalla osoittaa kohti vajan kattorakennelman kulmaa ja elehtii kulmaraudan muotoa ja kokoa käsillään (r. 1). Alanin seuraava vuoro osoittaa, että hän ymmärtää heti, mitä Ralf on etsimässä ja viittaa kulmarautaan kuvauksella sama metalli. Tämä ilmaus osoittaa, että rakentajat ovat käsitelleet kulmarautoja jo aikaisemminkin. Kysymys on siis molemmille tutusta asiasta; vain esineen nimi on kateissa.

Kun Alan ymmärtää, mitä Ralf on hakemassa, rakentajat lähtevät kävelemään kohti tarvikevarastoa (r. 10). Matkalla Ralf selittää, että "siellä on valmista". Esimerkin jatko osoittaa, että hän käyttää valmis-sanaa merkityksessä lорpu: kulmarautoja ei ole varastossa, koska ne ovat loppuneet. Alan toteaa eksplisiittisesti, että hän ymmärtää, mitä Ralf tarvitsee (r. 15), mutta Ralf vastaa naurahdellen, että Alanin ymmärryksellä ei ole niin väliä vaan tärkeämpää on, että Sami eli heidän opettajansa

Esimerkki 4b. Kulmaraudan pyytäminen ymmärtää (r. 17-18). Riveillä 21-24 olevan vuoron aikana rakentajat tutkivat tarvikelaatikoita ja Ralf toteaa, että (oikeankokoisia) kulmarautoja ei ole ja että hän haluaa kysyä opettajalta, miksi niitä nimitetään. Alan ottaa tehtävän itselleen ja kysyy saman tien lähellä olevalta Samilta, mikä kulmarautojen nimi on. Kun opettaja sanoo sanan (r. 32), Ralf toistaa sen (r. 33). Pian tämän jälkeen Alan kehottaa häntä menemään suurempaan varastoon kysymään asiasta. Lähtiessään Ralf jälleen toistaa kulmarauta-sanan nousevalla sävelkululla ja Alan vahvistaa sanan toistamalla sen seuraavassa vuorossa tasaisemmalla sävelkululla (r. 38-39).

Kun kulmarautaa ei sitten ole löytynyt siitä varastosta, josta Ralf sitä lähti etsimään esimerkin 4a lopussa, rakentajat lähestyvät toista opettajaa. Tässä Ralf käyttää sanaa sujuvasti ilmoittaessaan opettajalle tarvitsevansa kulmarautaa (r. 1).

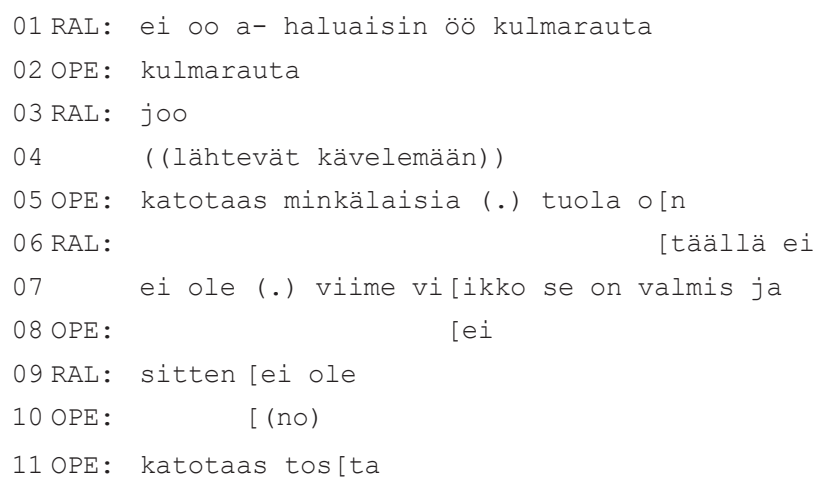

Yhdessä opettajan kanssa rakentajaopiskelijat sitten etsivät jälleen kulmarautoja, joita ei löydy. Kun kulmarautoja ei löydy, päätetään pitää kahvitauko ja kysyä kahvitauon jälkeen varaston vastaavalta, olisiko kulmarautoja mahdollisesti vielä jossain. Kahvitauon jälkeen, ennen varaston vastaavalle puhumista, kulmaraudat nousevat jälleen keskustelun aiheeksi. Esimerkin $4 \mathrm{c}$ alussa kahvitauolta palaava Alan (r. 1) toteaa työn nyt jatkuvan. Ralf on kuitenkin erimielinen ja perustelee, että työ ei voi jatkua, koska tarvitaan kulmarautoja. Hän ei kuitenkaan pääse vuorossaan kulmarauta-sanaan saakka vaan tuottaa epäröintiäänteen (r. 5) ja pitkän tauon jälkeen Alan jatkaa osoittamalla ymmärrystä joo- 
dialogipartikkelilla ja kolmio-sanalla (r. 7). Ralf hakee jälleen kulmaraudan nimeä (r. 8, 10). Aikaisemman keskustelun pohjalta molemmat siis ymmärtävät, mihin tässä viitataan, mutta itse sana on uudelleen hukassa. Kun opiskelijat keskustelevat sanasta, tutkija puuttuu keskusteluun ja tuo siihen mukaan kulmarauta-sanan (r. 13). Jälleen Ralf toistaa sanan (r. 14) ja sitten vielä toteaa, että hän ei halua unohtaa sanaa. Tämän jälkeen hän kirjoittaa sen vajan lattialautaan (ks. kuva 6) ja selittää, että on unohtanut sanan (r. 25).

Esimerkki 4c. Kulmarauta-sanan muistelu

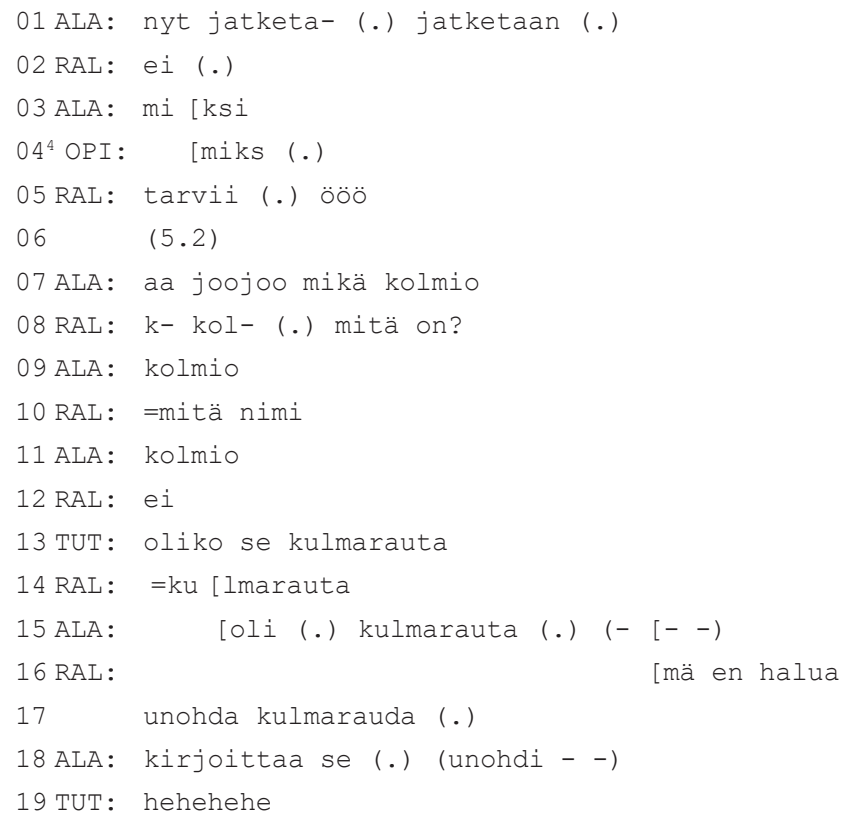

4 OPI on kolmas vain tässä tilanteessa mukana oleva opiskelija, joka ei kuitenkaan osallistu keskusteluun kovin aktiivisesti.

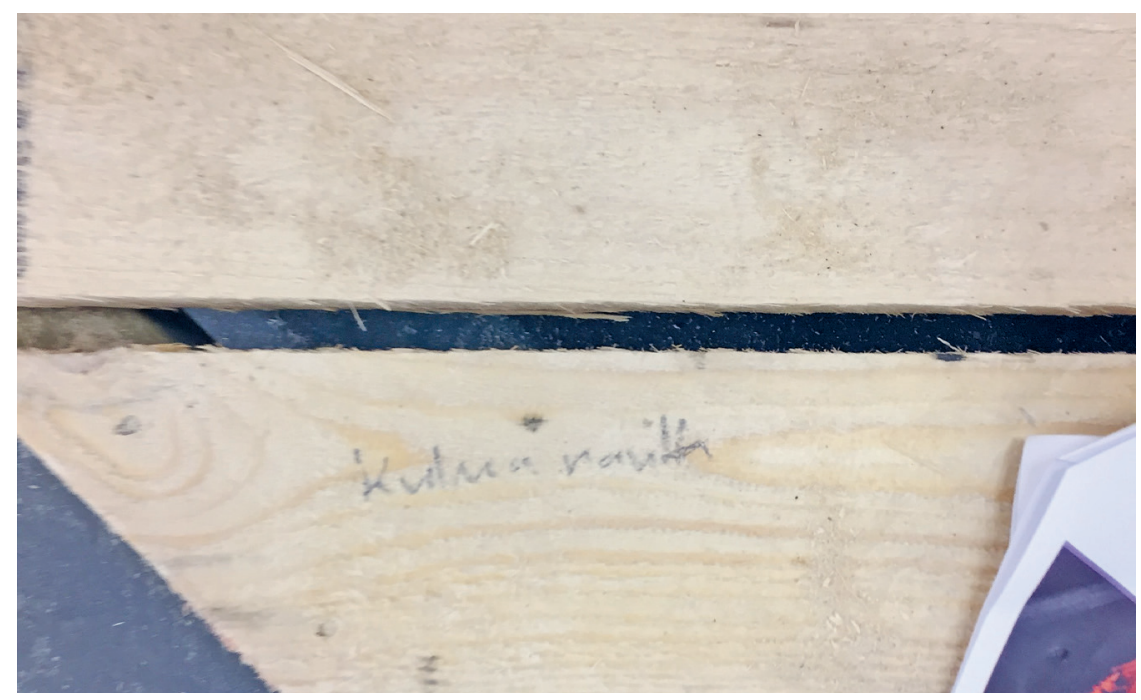




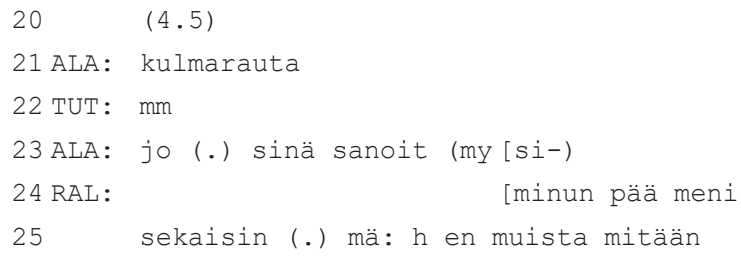

Kokonaisuudessaan tämä aineistonäyte havainnollistaa tilannetta, jossa rakentajaopiskelijat keskittyvät kieleen eli tietyn ammattisanastoon kuuluvan sanan etsimiseen, käyttämiseen ja mieleenpainamiseen. Huomio kulmarauta-sanaan syntyy tarpeen kautta: rakennustyössä on tarve kulmaraudoille, joita ei löydy varastolaatikoista, koska ne ovat loppuneet. Tästä syystä kulmaraudoista on keskusteltava opettajien ja varastosta vastaavien henkilöiden kanssa ja tässä keskustelussa tarvitaan sanaa. Sanan tarve siis liittyy erityisesti tilanteeseen, jossa siitä on puhuttava muualla kuin siinä välittömässä materiaalisessa ympäristössä, jossa esine on läsnä ja jossa sitä käytetään.

Oppimisen näkökulmasta esimerkki osoittaa, miten sanan mieleenpainaminen pelkän suullisen syötöksen kautta voi olla haasteellista myös tällaisissa tilanteissa, joissa kielenkäyttäjillä on selvä tarve ja motivaatio sanan oppimiseen. Tutkimuksissa usein korostuu ajatus siitä, että oppiminen on tehokkaimmillaan silloin, kun opiskeltava aines motivoituu todellisesta tarpeesta ja kielenkäyttäjälle merkityksellisestä kielenkäyttötilanteesta (ks. Lilja \& Piirainen-Marsh, 2018). Näin näyttäisi tässä tilanteessa olevan. Näyte kuitenkin havainnollistaa myös sitä, että edes tarpeellinen sana ei välttämättä heti jää mieleen vaan saattaa häipyä muistista jo kahvitauon aikana. Siksi on huomionarvoista, että Ralf tässä kirjoittaa sanan vajan lattiaan. Sanan kirjoittaminen on sen muistiinmerkitsemistä, ja kirjoitettuna sana on näkyvillä: sitä voi katsella ja lukea ohi mennessään ja samalla havainto sanasta toistuu, mikä voi helpottaa sen muistamista. Tämäkin näyte havainnollistaa sitä, että kielen näkyväksi tekeminen on yksi keino tukea kielen käyttöä ja haltuun ottamista työtilanteissa. Ja vaikka sanaa ei olisikaan kirjoitettu muistiin, toistuessaan tämänkaltaiset yksittäisiin ilmauksiin fokusoivat vuorovaikutustilanteet kuitenkin varmasti edesauttavat oppimista, koska oppijoiden huomio kiinnittyy eksplisiittisesti opittavaan ainekseen.

\section{LOPUKSI: KIELEN KÄYTÖN JA OPPIMISEN TUKEMISESTA AMMATTIALOILLA}

Olemme tässä artikkelissa kuvanneet suomen kielen käyttöä rakennusalan työtehtävissä. Tutkimuksemme lähti liikkeelle tarpeesta saada tietoa rakennusalan työtehtäville tyypillistä kielikäytänteistä. Tällaista tietoa tarvitaan, jotta olisi mahdollista kehittää pedagogisia ratkaisuja, joilla voitaisiin tukea suomi toisen kielenä -puhujien kielen käyttöä ja oppimista työelämän vuorovaikutustilanteissa, kuten nykyiset kotoutumiskoulutuksen linjaukset edellyttävät. Lisäksi on tarpeen ymmärtää syvällisemmin kielen roolia erilaisissa suorittavan työn tehtävissä.

Keskeinen havaintomme, jota olemme tässä myös havainnollistaneet aineistonäyttein, on se, että rakennusalan työtehtävissä kielen käyttö on hyvin kiinteässä yhteydessä vuorovaikutustilanteen materiaaliseen ja fyysiseen ympäristöön. Vuorovaikutus on multimodaalista, ja osallistujien puhetta olisi usein vaikea ymmärtää, ellei näkisi, miten he elehtivät ja 
millaisessa fyysisessä ympäristössä he toimivat. Esimerkiksi työkalut ja työssä tarvittavat muut välineet näkyvät vuorovaikutuksessa ja jäsentävät sitä monin tavoin: niihin viitataan eleillä ja niistä puhumisessa tarvittavaa sanastoa etsitään ja yritetään muistaa. $\mathrm{Ha}$ vaintomme nostavatkin esiin tarpeen tutkia erityisesti suorittavan työn kielikäytänteitä nimenomaan multimodaalisesta näkökulmasta. Kielenkäytöstä on mahdoton saada koko kuvaa, jos ei ole mahdollista analysoida sitä, mitä työntekijät puhuessaan tekevät ja millaiset materiaalit tilanteessa ovat olennaisia.

Analyysimme osoittaa myös, että rakennusalan vuorovaikutustilanteissa - erityisesti ammatillisten opintojen kontekstissa - korostuu ohjaileva toiminta: rakennustoiminnassa tarvitaan taitoa ohjeistaa työtovereita ja pyytää heiltä työkaluja tai apua. Havaintojemme perusteella näyttää siltä, että erilaisten direktiivisten vuorojen muotoilun ja ymmärtämisen taito on siis olennaista työtehtävissä pärjäämisen kannalta. Direktiivit toteutuvat aineistossamme monenlaisin kielellisin rakentein. Esimerkki 1 havainnollisti opettajan antamaa ohjeistusta, joka sisälsi yksipersoonaisia verbejä, imperatiiveja ja nesessiivirakenteita. Usein ohjeet onkin muotoiltu passiivimaisiksi: niitä ei kohdisteta suoraan opiskelijalle vaan niissä esitetään se, mitä tilanteessa olisi hyvä tehdä ja millainen on toivottu lopputulos. Opiskelijoiden omissa opiskelijakollegoille suunnatuissa direktiiveissä, esimerkiksi juuri pyynnöissä, näkyy toiminnan ensisijaisuus: opiskelijat ymmärtävät toisiaan hyvin, vaikka pyyntöjä ei kokonaan verbalisoidakaan.

Erilaiset direktiiviset vuorot eli vuorot, jotka pyrkivät saamaan vastaanottajan toimimaan tietyllä tavalla (ks. Goodwin, 1990; Stevanovic \& Svennevig, 2015; VISK, \$1645), saivat paljon huomiota myös Holmesin ja Woodhamsin (2013) rakennusalan kielikäytänteitä analysoivassa tutkimuksessa. He ha- vaitsivat, että työn organisoinnissa käytetyt direktiivit olivat rakenteeltaan moninaisia: käytettiin niin eksplisiittisiä imperatiiveja kuin epätäsmällisempiä muotoiluja, joiden ymmärtäminen vaati työn yksityiskohtien tuntemusta. Heidän analyysinsa mukaan direktiivien käyttö kertoi jotakin myös työntekijän asemasta työyhteisön hierarkiassa. Esimiesasemassa olevat kokeneet työntekijät käyttivät enemmän imperatiivimuotoja erityisesti työharjoittelijoille puhuessaan kuin vuorovaikutuksessa muiden työntekijöiden kanssa. Holmesin ja Woodhamsin analyysi perustui kuitenkin ääninauhoitettuun aineistoon, eikä heillä näin ollen ole ollut mahdollisuutta analysoida direktiivisten vuorojen yhteyttä siihen materiaaliseen ympäristöön, jossa niitä käytetään. Tässä esittämämme analyysi täydentää Holmesin ja Woodhamsin analyysia osoittamalla, miten direktiivien muotoilu on kytköksissä myös puheen sekventiaaliseen asemaan, meneillään olevan toiminnan materiaaliseen ekologiaan sekä siihen, mitä osallistujat ovat tekemässä tai mitä he todennäköisesti tekevät seuraavaksi (samankaltaisista havainnoista esimerkiksi arkikeskusteluaineistoissa ks. esim. Rossi, 2014, 2015; Sorjonen ym., 2017).

Vuorovaikutuksen ja kielen käytön kiinteä kytkeytyminen tilanteen materiaaliseen ekologiaan on kielen käytön ja erityisesti kielen oppimisen kannalta ajatuksia herättävä tilanne. Toisaalta aineistostamme ja tässä esittämistämme näytteistä näkyy selvästi se, että materiaalinen ympäristö tukee vuorojen muodostamista ja myös ymmärtämistä: kun tarvittavat työvälineet ovat tilanteessa läsnä tai ainakin jossakin lähellä, niihin voi konkreettisesti viitata joko osoittavilla eleillä tai kuvailemalla elein sitä toimintaa, johon niitä tarvitaan (esimerkit 1-4). Tässä mielessä materiaalisen ympäristön sinänsä voi ajatella tukevan kielen käyttöä. Rakennusmateriaalit toimivat näin mahdollisesti "rakennustelinei- 
nä" (scaffold) myös kielen oppimiselle (van Lier, 2004). Aineistomme havainnollistaa, että osallistujat ymmärtävät toisiaan ja osaavat toimia hyvin tarkoituksenmukaisesti niiden materiaalisten resurssien avulla, jotka ovat tilanteessa läsnä ja tarpeen. Voi ehkä ajatella, että kun jotakin tiettyä työkalua pyytää tarpeeksi monta kertaa työkaverilta eleen avulla ja kun työkaveri vielä toistaa työvälineen nimen pyyntöä seuraavassa vuorossa, oppimista tapahtuu tilanteiden toistuessa pitkän aikavälin kuluessa.

Toisaalta kielen käytön tilanteisuuteen ja materiaalisuuteen liittyy kuitenkin kysymys kielellisten käytänteiden siirtymisestä tilanteesta toiseen (ks. Larsen-Freeman, 2004). Siksi on olennaista kysyä, missä määrin nämä kiinteästi tiettyyn materiaaliseen ympäristöön sidotut vuorovaikutuskäytänteet ovat siirrettävissä tosiin vuorovaikutusympäristöihin. Esimerkki 4 havainnollisti, miten kulmarauta-sana löytyi opettajan tuella tilanteessa, jossa kulmarautaa etsittiin laatikosta. Opiskelijat olivat hyvin motivoituneita käyttämään sanaa ja muistamaan sen, mikä näkyi lukuisissa sanan toistoissa. Sanaa oli kuitenkin vaikea muistaa enää kahvitauon jälkeen tilanteessa, jossa kulmarautaa ei enää ollut konkreettisesti läsnä. Pedagogisessa mielessä analyysimme siis kannustaa myös pohtimaan, miten opiskelijoiden omaa kielellisten aineisten (sanojen, rakenteiden, vuorovaikutuskäytänteiden) havaitsemista voisi tukea ja miten heitä voisi ohjata esimerkiksi tallentamaan kieltä niin, että siihen voisi palata myöhemmin, jotta pitkäkestoinen oppiminen ja muistaminen mahdollistuisi. Esimerkki 4 havainnollisti myös sitä, että opiskelijat luontaisesti pyrkivät tallentamaan merkityksellisiä kielenaineksia, kun Ralf kirjoitti sanan, koska ei halunnut sitä unohtaa.

Analyysimme nostaa monia ajatuksia pedagogiikan kehittämiseen. Kielen käyttöä tilanteissa edesauttaa se, että kieli ja esimerkiksi keskeisten työvälineiden nimet ovat helposti näkyvissä myös tekstinä työympäristössä. Tällainen työympäristöjen kielimaisemiin panostaminen edellyttää kielitietoisuutta mutta saattaa myös lisätä sitä muidenkin kuin kieltä oppivien keskuudessa (Laihonen \& Szabo, 2018). Erityisesti havainto siitä, että työtehtäviin liittyvien asioiden kielentäminen voi olla haastavaa muualla kuin siinä konkreettisessa ympäristössä, jossa työtä tehdään, on pedagogisessa mielessä tärkeä. Vaikka kielen oppiminen onkin tilanteinen prosessi, kielen osaaminen tarkoittaa myös kykyä toimia tarkoituksenmukaisesti useissa tilanteissa - ei vain yhdessä (ks. Hall, Hellermann \& Pekarek Doehler, 2011). Rakennusalan työtehtävissä tarvittavan kielen opiskelua todennäköisesti tukee se, että työtehtävät ja työryhmät vaihtuvat säännöllisesti ja että opiskelijoiden tulee jossakin muodossa raportoida tekemisistään joko suullisesti tai kirjallisesti. Vaikka tällaisia hetkiä ei ole tallentunut tähän aineistoomme, havainnointiviikon aikaisista informaaleista keskusteluista opettajien ja opiskelijoiden kanssa saimme tietää, että näin tapahtuu. Esimerkiksi raportointi on erilainen kielenkäyttötilanne kuin fyysisen työn osana tapahtuva vuorovaikutus, ja siksi se voi tuoda eri tavalla tietoiselle tasolle esimerkiksi rakennusalan erikoissanastoa kuin tämän sanaston käyttäminen työn lomassa.

Aineistomme on kerätty yhden viikon aikana ja on siksi rajallinen. Olisikin tarvetta pidempikestoiselle tutkimukselle, jossa seurattaisiin sitä, miten siirtyminen kotoutumiskoulutuksesta työharjoitteluun tai työelämään sujuu ja missä määrin koulutuksessa opitut kielikäytänteet ovat niitä, joita työelämässä tarvitaan. Tällainen tutkimus auttaisi ymmärtämään paremmin sitä, millaiset painotukset opetuksen sisällöissä olisivat tarkoituksenmukaisia. Toisaalta tarvitaan edelleen myös syvällisempää ja laajempaa ymmärrystä työelämän kielikäytänteistä - 
erityisesti niiltä aloilta, joille maahanmuuttajataustaisia aikuisia työllistyy runsaasti. Näitä käytänteitä on tarpeen tutkia autenttisista aineistoista, jotta päästään analysoimaan sitä, mitä tilanteissa todella tapahtuu ja millaista kieltä niissä tarvitaan (ks. myös Pyykkö, 2017). Aineistomme saattaa erota "todellisen" työelämän tilanteista esimerkiksi siinä, että oppilaitoksessa aikapaine ja kiire tehtävien tekemisessä ei todennäköisesti ole yhtä lailla läsnä ja vaikuttamassa kielikäytänteisiin kuin työelämässä. Rakennusala on yksi maahanmuuttajia paljon työllistävä ala, ja siksi lisätutkimus tältä alalta on tarpeen. Toinen suuri työllistäjä on sosiaali- ja terveysala, jonka kielikäytänteistä ja kielitaitotarpeista tehdäänkin parhaillaan aktiivisesti tutkimusta (ks. esim. Komppa, Kurhila \& Lehtimaja, 2017; Seilonen \& Suni, 2016; Tervola, Pajunen, Vainio, Honko \& Mattila, 2015; Virtanen, 2017).

Muutokset kotoutumiskoulutuksen painotuksissa ja myös ammatillisen koulutuksen muutosprosessit johtavat siihen, että oppijoilta vaaditaan yhä enemmän opiskelutaitoja ja kykyä itsenäiseen oppimiseen. Kielikoulutuksen yhtenä tärkeänä tavoitteena onkin opettaa opiskelijoille taitoja kiinnittää huomiota kieleen (vrt. Svennevig, 2017) ja reflektoida omia kielenkäyttökokemuksiaan. On siis entistä tärkeämpää oppia oppimaan itsenäisesti erilaisissa vuorovaikutustilanteissa. Kotoutumiskoulutuksen vuonna 2012 julkaistu opetussuunnitelma on vielä voimassa eikä kotoutumislaissa määriteltyä kielitaidon tavoitetasoa B1.1. ole muutettu, vaikka koulutuksen uudet toteuttamismallit painottavat kielen sijaan entistä enemmän työelämäsisältöjä sekä ammatillisen kielen hallintaa. Kotoutumiskoulutuksen kestoa ei ole pidennetty, joten koulutus on edelleen noin vuoden mittainen. Kielitaidon tavoitetason saavuttaminen voi olla entistä hankalampaa monelle opiskelijalle, jos koulutus yhä enemmän tapahtuu työpaikoilla ja työn ohessa ja vaatii hyvin itsenäistä otetta. Turun ja pääkaupunkiseudun alueella uusien kotouttamiskoulutuksen toteuttamismallien toimivuudesta tehdyn selvityksen perusteella esimerkiksi pääkaupunkiseudulla sosiaali- ja terveysalaa painottavassa ryhmässä 34 prosenttia opiskelijoista saavutti kielitaidon tavoitetason, mutta teknologia-alan ryhmässä vain 11 prosenttia. Tulos voi johtua valittujen alojen erilaisesta kielipainottuneisuudesta, mutta myös alalle hakeutuneiden opiskelijoiden taustoista ja taidoista (ks. Uudenmaan ELY, 2018).

Tavoite ammatillisen kielen painottamiseen osana kotoutumiskoulutusta on toisaalta hyvin perusteltu, koska ammatillinen kielitaito sujuvoittaa työelämään siirtymistä ja auttaa pärjäämään työelämän vuorovaikutustilanteissa. Toisaalta yhtä tärkeä on muistaa myös kotoutumiskoulutuksen tavoite tukea maahanmuuttajien aktiivista osallistumista suomalaisen yhteiskunnan toimintaan ja luoda edellytyksiä avoimelle demokratialle. Tämä edellyttää paitsi ammatillista kielitaitoa myös taitoa toimia monissa erilaisissa vuorovaikutustilanteissa tarkoituksenmukaisesti. Kotoutuminen ei pysähdy työllistymiseen. Suomen kielen oppimisen jatkuvuudesta olisi huolehdittava työllistymisen jälkeenkin niin, että jokainen saisi edelleen tarvitsemaansa tukea kielitaidon kehittämiseen. Tarvitaan siis lisää kotoutumiskoulutukseen kohdistuvaa tutkimusta ja sen selvittämistä, miten erilaiset koulutusratkaisut toimivat ja miten niitä voisi kehittää, niin että lopputulos olisi toimiva niin kotoutujien kuin yhteiskunnankin kannalta.

\section{LÄHTEET}

Arjen vuorovaikutusta muotoilemassa. (2018). Tutkimusprojektin internet-sivut. Haettu 7.9.2018 osoitteesta https://research.uta.fi/ avut/

Eduskunta (2018) = Ala-Kauhaluoma, M., Pitkä- 
nen, S., Ohtonen J., Ramadan, F., Hautamäki, L., Vuorento, M. \& Rinne, H. (2018). Monimenetelmäinen tutkimus kotouttamistoimenpiteiden toimivuudesta. Eduskunnan tarkastusvaliokunnan julkaisu 1/2018. Helsinki: Eduskunta. Haettu 7.9.2018 osoitteesta https://www. eduskunta.fi/FI/tietoaeduskunnasta/julkaisut/ Documents/trvj_1+2018.pdf

Eskildsen, S. W. \& Wagner. J. (2013). Recurring and shared gestures in the L2 classroom: Resources for teaching and learning. European Journal of Applied Linguistics, 1, 139-161.

Goldstein, T. (1996). Two languages at work: Bilingual life on the production floor. Berlin: Mouton de Gruyter.

Goodwin, C. (2000). Action and embodiment within situated human interaction. Journal of Pragmatics, 32, 1489-1522.

Goodwin, C. (2007). Environmentally coupled gestures. Teoksessa E. Levy, J. Cassell \& S. Duncan (toim.), Gesture and the dynamic dimensions of language, (s. 195-212). Amsterdam: John Benjamins.

Goodwin, M.H. (1990). He-said-she-said. Talk as social organization among black children. Bloomington, IN: Indiana University Press.

Hall, J. K., Hellermann, J. \& Pekarek Doehler, S. (toim.) (2011). The development of interactional competence. Bristol: Multilingual Matters.

Hallituksen kotouttamista koskeva toimintasuunnitelma. (2016). Haettu 7.9.2018 osoitteesta https://vnk.fi/documents/10616/1266558/ Kotouttamisen-toimintasuunnitelma-030516. pdf/c600bd8f-7c5c-43b6-aba4-5aade9aafe0d/ Kotouttamisen-toimintasuunnitelma-030516. pdf.pdf

Holmes, J. \& Woodhams, J. (2013). Building interaction: The role of talk in joining a community of practice. Discourse and Communication, 7, 275-298.

Johansson, M., Nuolijärvi, P. \& Pyykkö, R. (toim.) (2011). Kieli työssä: Asiantuntijatyön kielelliset käytännöt. Helsinki: Suomalaisen Kirjallisuuden Seura.

Joyce, P. (2018). Newcomers in the North: Labor market integration of refugees in Northern Europe. Haettu 7.9.2018 osoitteesta https:// www.migrationpolicy.org/article/newcomersnorth-labor-market-integration-refugees-northern-europe
Kalliokoski, J. (2017). Virkakielen ihanteet ja kielen omistajuus: S2-näkökulmia julkishallinnon kielenkäyttöön. Teoksessa S. Latomaa, E. Luukka \& N. Lilja (toim.), Kielitietoisuus eriarvoistuvassa ybteiskunnassa. AFinLAn vuosikirja, (s. 92-113). Haettu 7.9.2018 osoitteesta https:// journal.fi/afinlavk/article/view/60842

Karlsdóttir, A., Sigurjónsdóttir, H.R., Hildestrand, Å. \& Cuadrado, A. (2017). Policies and measures for speeding up labour market integration of refugees in the Nordic region: A knowledge overview. Nordregio working paper 8 . Stockholm: Nordregio. Haettu 7.9.2018 osoitteesta http://norden.diva-portal.org/smash/record.js f?pid=diva2\%3A1172581\&dswid=4164

Kieliparlamentti 2011 - Työelämän kieli-ja viestintätaidot (2011). Haettu 7.9.2018 osoitteesta https://www.kieliverkosto.fi/fi/toiminta/ tapahtumat/docs/kieliparlamentti-kannanotto-2011.pdf

KIITO - kiinni työhön ja osaamiseen. Haettu 7.9.2018 osoitteesta https://kiitohanke.wordpress.com/

Komppa, J., Kurhila, S. \& Lehtimaja I. (2017). Nyt tutkitaan vuorovaikutusta sairaanhoitajan työssä. Haettu 7.9.2018 osoitteesta https://sairaanhoitajat.fi/2017/34895/

Kraft, K. (2017). Constructing migrant workers. Multilingualism and communication in the transnational construction site. Väitöskirja. Oslo: Oslo University.

Laihonen, P. \& Szabo, T. (2018). Studying the visual and material dimensions of education and learning. Linguistics and Education, 44, 1-3.

Larsen-Freeman, D. (2004). CA for SLA? It all depends. The Modern Language Journal, 88, 603-607.

van Lier, L. (2004). The ecology and semiotics of language learning: A sociocultural perspective. Boston: Kluwer Academic

Lilja, N. \& Piirainen-Marsh, A. (2018). Connecting the language classroom and the wild: Reenactments of language use experiences. Applied Linguistics. https://doi.org/10.1093/applin/ amx045

Lønsmann, D. \& Kraft, K. (2017). Language in blue-collar workplaces. Teoksessa B. Vine (toim.), The Routledge handbook of language in the workplace, (s. 169-180). New York, NY: Routledge. 
Mondada, L. (2014). The local constitution of multimodal resources for social interaction. Journal of Pragmatics, 65, 137-156.

Mondada, L. (2016). Challenges of multimodality: Language and the body in social interaction. Journal of Sociolinguistics, 20, 336-366.

Mondada, L. (n.d). Conventions for multimodal transcription. Haettu 7.9.2018 osoitteesta https://franzoesistik.philhist.unibas.ch/filead$\mathrm{min} /$ user_upload/franzoesistik/mondada_ multimodal_conventions.pdf

Mori, J. \& Hayashi, M. (2006). The achievement of intersubjectivity through embodied completions: A study of interactions between first and second language speakers. Applied Linguistics, 27, 195-219.

Nieminen, T., Sutela, H. \& Hannula U. (toim.) (2014). Ulkomaista syntyperää olevien työ ja hyvinvointi Suomessa 2014. Helsinki: Tilastokeskus. Haettu 7.9.2018 osoitteesta https://www. stat.fi/tup/julkaisut/tiedostot/julkaisuluettelo/yyti_uso_201500_2015_16163_net.pdf

$\operatorname{OECD}(2017)=$ Finding their way. Labour market integration of refugees in Germany. Haettu 7.9.2018 osoitteesta https://www.oecd.org/els/ mig/Finding-their-Way-Germany.pdf

OECD (2018) = Working together: Skills and labour market integration of immigrants and their children in Finland. Haettu 15.1.2019 osoitteesta http://www.oecd.org/publications/ working-together-skills-and-labour-marketintegration-of-immigrants-and-their-childrenin-finland-9789264305250-en.htm

Olsher, D. (2004). Talk and gesture: The embodied completion of sequential actions in spoken interaction. Teoksessa R. Gardner \& J. Wagner (toim.), Second Language Conversations, (s. 221-245). London: Continuum.

OPH (2012) = Aikuisten maahanmuuttajien kotoutumiskoulutuksen opetussuunnitelman perusteet 2012. Opetushallitus. Haettu 7.9.2018 osoitteesta http://www.oph.fi/ download/139342_aikuisten_maahanmuuttajien_kotoutumiskoulutuksen_opetussuunnitelman_perusteet_2012.pdf

Piller, I. \& Lising. L. (2014). Language, employment and settlement: Temporary meat workers in Australia. Multilingua: Journal of CrossCultural and Interlanguage Communication, 33, 35-59.
Pyrhönen, N., Leinonen, J. \& Martikainen, T. (2017). Nordic migration and integration research: overview and future prospects. Policy paper 3/2017. Oslo: Nordforsk. Haettu 7.9.2018 osoitteesta

https://www.nordforsk.org/en/publications/ publications_container/nordic-migrationand-integration-research-overview-and-futureprospects

Pyykkö, R. (2017). Monikielisyys vahvuudeksi. Selvitys Suomen kielivarannon tilasta ja tasosta. Opetus- ja kulttuuriministeriön julkaisuja 2017:51. Helsinki: Opetus- ja kulttuuriministeriö. Haettu 7.9.2018 osoitteesta http:// julkaisut.valtioneuvosto.fi/bitstream/handle/10024/160374/okm51.pdf

Päivitetyt kotoutumiskoulutuksen toteutusmallit 2017 (2017). Opetushallitus. Haettu 7.9.2018 osoitteesta https://www.oph.fi/download/188626_koto_koulutusmalleja_2017_final_verkkoon_vietavaksii_final_Kallelle.pdf

Rossi, G. (2014). When do people not use language to make requests? Teoksessa P. Drew \& E. Couper-Kuhlen (toim.), Requesting in social interaction, (s. 303-334). Amsterdam: John Benjamins.

Rossi, G. (2015). The request system in Italian interaction. Väitöskirja. Nijmegen: Radboud University.

Sandberg. T. \& Strodell, E. (2016). Vastaanottokeskuksissa toteutettu alkuvaiheen osaamisen tunnistaminen. Helsinki: Testipiste. Haettu 7.9.2018 osoitteesta https://minedu. fi/documents/1410845/4240776/VOKraportti_2016/86ea0123-d929-4aa6-b45395eaa1ec2dd7/VOK-raportti_2016.pdf

Seilonen, M. \& Suni, M. (2016). Ohjeita, tietoa ja turvaa kielen keinoin. Ulkomailta palkatut sairaanhoitajat ammatillista suomen kielen taitoaan osoittamassa. Lähivertailuja - Lähivôrdlusi, 26, 450-480. Haettu 15.1.2019 osoitteesta online: http://arhiiv.rakenduslingvistika.ee/ ajakirjad/index.php/lahivordlusi/article/ view/LV26.15/397

Seppänen, E.-L. (1997). Vuorovaikutus paperilla. Teoksessa L. Tainio (toim.), Keskustelunanalyysin perusteet, (s. 18-31). Tampere: Vastapaino.

Sorjonen, M.-L., Raevaara, L. \& Couper-Kuhlen, E. (toim.) (2017). Imperative turns at talk. The design of directives in action. Studies in langu- 
age and social interaction 30. Amsterdam: John Benjamins.

Social Impact Bond. Maahanmuuttajien kotouttamisen SIB-hanke. Haettu 7.9.2018 osoitteesta https://tem.fi/koto-sib

Stevanovic, M. \& Svennevig, J. (2015). Introduction: Epistemics and deontics in conversational directives. Journal of Pragmatics, 78, 1-6.

Strömmer, M. (2017). Mahdollisuuksien rajoissa. Neksusanalyysi suomen kielen oppimisesta siivoustyössä. Väitöskirja. Jyväskylä: Jyväskylän yliopisto.

Sutela, H. (2015). Ulkomaalaistaustaiset työelämässä. Teoksessa T. Nieminen, H. Sutela \& U. Hannula (toim.), Ulkomaalaista työperää olevien työ ja hyvinvointi Suomessa 2014, (s. 83109). Helsinki: Tilastokeskus. https://www. stat.fi/tup/julkaisut/tiedostot/julkaisuluettelo/yyti_uso 201500 2015 16163 net.pdf

Svennevig, J. (2017). "What's it called in Norwegian?” Acquiring L2 vocabulary items in the workplace. Journal of Pragmatics, 126, 68-77.

Tervola, M., Pajunen, A., Vainio, S. Honko, M. \& Mattila, K. (2015). Maahanmuuttajataustaisten lääkärien suomen kielen taito laillistamiskuulustelussa. Duodecim, 131, 339-346.

Thompson, S., Fox, B., Couper-Kuhlen, E. (2015). Grammar in everyday talk. Cambridge: Cambridge University Press.

Uudenmaan ELY (2018) = Selvityskotoutumiskou- lutuksen malleista Turussa ja pääkaupunkiseudulla. Haettu 7.9.2018 osoitteesta http://www. ely-keskus.fi/documents/10191/20388605/ Kotoselvitys_09_04_18.pdf/341dcdd8-f5e84eac-b667-a9043bf4a012

Vaattovaara, J. (2017). Akateemisten työläisten kertomaa: viestintä, kielitaito ja kielitietoisuus asiantuntijatyössä. Teoksessa S. Latomaa, E. Luukka \& N. Lilja (toim.), Kielitietoisuus eriarvoistuvassa yhteiskunnassa. AFinL An vuosikirja, (s. 298-319). Haettu 7.9.2018 osoitteesta https://journal.fi/afinlavk/article/view/60727

Valtion kotouttamisohjelma vuosille 2016-2019. Haettu 7.9.2018 osoitteesta https://tem.fi/documents/1410877/3506436/Valtion+kotoutt amisohjelma+vuosille+2016-2019.pdf

Virtanen, Aija 2017. Toimijuutta toisella kielellä: kansainvälisten sairaanhoitajaopiskelijoiden ammatillinen suomen kielen taito ja sen kehittyminen työharjoitteluissa. Jyväskylä studies in humanities 311. University of Jyväskylä: Jyväskylä. Haettu 15.1.2019 osoitteesta http://urn. fi/URN:ISBN:978-951-39-7021-5

VISK (2004). Hakulinen A., Vilkuna M., Korhonen, R., Koivisto, V., Heinonen, T.R. \& Alho, I. (toim.). Iso suomen kielioppi. Helsinki: Suomalaisen kirjallisuuden seura. Verkkoversio. Haettu 7.9.2018 osoitteesta http://scripta.kotus.fi/ visk/etusivu.php 
LIITE 1. Litteraatiomerkit

\section{SÄVELKULKU}

Prosodisen kokonaisuuden lopussa

\begin{tabular}{ll}
$\cdot$ & laskeva intonaatio \\
$?$ & tasainen intonaatio \\
joo & nouseva intonaatio \\
\hline
\end{tabular}

\section{PÄÄLLEKKÄISYYDET JA TAUOT}

[ päällekkäispuhunnan alku

] pälllekkäispuhunnan loppu

(.) mikrotauko: 0.2 sekuntia tai vähemmän

(0.5) mikrotauko pidempi tauko; pituus sekunnin kymmenesosina

$=\quad$ kaksi vuoroa liittyvät toisiinsa tauotta

\section{PUHENOPEUS JA ÄÄNEN VOIMAKKUUS}

$>\quad$ nopeutettu jakso

$<\quad$ hidastettu jakso

joo: äänteenvenytys

JOO äänen voimistaminen

\section{MUITA MERKKEJÄ}

se- $\quad$ (tavuviiva); sana jäänyt kesken

(joo) epäselvästi kuultu sana tai jakso

(-) sana, josta ei ole saatu selvää

(---) pitempi jakso, josta ei ole saatu selvää

Kehollinen toiminta on litteroitu Mondadan (n.d.) kehittämiä konventioita noudattaen, ks. https:// franzoesistik.philhist.unibas.ch/fileadmin/user_upload/franzoesistik/mondada_multimodal_conventions.pdf. Eri osallistujien eleisiin viittaavat merkit on selitetty jokaisen esimerkkikatkelman alussa. 


\section{USING AND LEARNING FINNISH AS A SECOND LANGUAGE IN CONSTRUCTION SITE INTERACTION}

Niina Lilja, Tampere University

Terhi Tapaninen, Tampere University and Tampere Adult Education Centre

Recent new arrangements of integration learning for adult immigrants to Finland emphasize the importance of work-specific language skills. In order to speed up labour market integration, new models of integration learning have been introduced in which language learning is combined with vocational education. While these new models have the potential of supporting immigrants in finding their paths to labour market in an efficient way, they also bring about challenges for language teaching. This is especially because research on language practices in blue-collar work is still scarce.

In this paper, we aim is to provide new information about language practices in construction work. By using multimodal conversation analysis as a method, we show how language practices are tightly connected to the material ecology of the construction site setting. In organizing the collaborative teamwork, the co-workers need to direct and advice each other and negotiate challenging situations. The data consists of audio- and video recordings of L2 interactions at a construction site in a vocational school.

Keywords: blue-collar work, conversation analysis, Finnish as a second language, interaction, language learning, language at work, learning 